\title{
Hydrochemistry and Diatom Assemblages on the Humpata Plateau, Southwestern Angola
}

\author{
Elena Robakiewicz ${ }^{1,2,3, *}$, Daniela de Matos $4,5,6,7$ (D) Jeffery R. Stone ${ }^{8}$ and Annett Junginger ${ }^{2,3}(\mathbb{D})$ \\ 1 Department of Geosciences, University of Connecticut, Beach Hall, 354 Mansfield Rd \#207, Storrs, CT 06269, USA \\ 2 Department of Geosciences, Universität Tübingen, 72072 Tübingen, Germany; \\ annett.junginger@uni-tuebingen.de \\ 3 Senckenberg Center for Human Evolution and Paleoenvironment (S-HEP), 72072 Tübingen, Germany \\ 4 Institute for Archaeological Sciences, Universität Tübingen, 72072 Tübingen, Germany; \\ daniela.de-matos@uni-tuebingen.de \\ 5 Instituto Terra e Memória, Largo Infante Dom Henrique, Museu de Arte Pré-Histórica, \\ 6120-524 Mação, Portugal \\ 6 Centro de Geociências da Universidade de Coimbra, 3000-456 Coimbra, Portugal \\ 7 Instituto Politécnico de Tomar, Quinta do Contador, 2300-313 Tomar, Portugal \\ 8 Department of Earth and Environmental Systems, Indiana State University, Terre Haute, IN 47809, USA; \\ Jeffery.Stone@indstate.edu \\ * Correspondence: elena.robakiewicz@uconn.edu
}

Citation: Robakiewicz, E.; de Matos, D.; Stone, J.R.; Junginger, A.

Hydrochemistry and Diatom Assemblages on the Humpata Plateau, Southwestern Angola. Geosciences 2021, 11, 359. https:// doi.org/10.3390/geosciences11090359

Academic Editors: Inka Meyer and Jesus Martinez-Frias

Received: 26 June 2021

Accepted: 21 August 2021

Published: 25 August 2021

Publisher's Note: MDPI stays neutral with regard to jurisdictional claims in published maps and institutional affiliations.

Copyright: (c) 2021 by the authors. Licensee MDPI, Basel, Switzerland. This article is an open access article distributed under the terms and conditions of the Creative Commons Attribution (CC BY) license (https:// creativecommons.org/licenses/by/ $4.0 /)$.

\begin{abstract}
Diatoms, a common siliceous alga, are effective paleoclimate and pollution indicators. They have been used in northern, eastern, and southern Africa as such because of well-documented ecologies of many taxa. In southwestern Africa, however, the country of Angola lacks similar modern assemblage studies. To close this gap, modern diatoms were sampled across four water bodies on the Humpata Plateau in southwestern Angola in the dry season of July 2019, with in-situ measurements of $\mathrm{pH}$, conductivity, and total dissolved solids and laboratory analysis of cations and anions. This research concludes that bedrock determines local hydrochemistry. In addition, this exploratory study finds that diatoms in southwestern Angola can infer relative conductivities and trophic levels, but limited data hinder interpretations of diatom ecological preferences of $\mathrm{pH}$, temperature, alkalinity, ions, and pollution, requiring further analyses. Such research is beneficial for both African diatomists interested in using accurate transfer functions across Africa to reconstruct paleoclimates as well as local communities and hydrologists interested in understanding water chemistry and pollution, given that these studied sites are vital water resources for local communities on the Humpata Plateau.
\end{abstract}

Keywords: water quality; conductivity; algae; $\mathrm{pH}$

\section{Introduction}

Water is a valuable resource, particularly for populations in the dry subhumid Humpata Plateau in southwestern Angola. Beyond consumption and food preparation, daily economic tasks depend on water, including excremental waste management, agriculture, livestock production, washing, fishing, and other economic activities [1]. The use of water for these activities can lead to pollution, which reduces individuals' access to clean, fresh water [2]. Although in recent years Angola has established policies to decrease water pollution (whether from heavy metals, agriculture, industry, or excremental waste) and increase water quality [2], in much of the country, little is known about local water chemistry, particularly beyond urban areas [1,3]. Studies of rural water sources are limited because many techniques used to manage and analyze water are time consuming and access to collection sites is limited due to a lack of roads in many rural communities across the country [4]. This emphasizes the importance for communities to have in-depth knowledge about their local water supplies and adopt practices that support community-based monitoring to keep waters clean [5]. 
In environments with variable annual precipitation such as the Humpata Plateau, water access is even more crucial. Most accessible and potable water comes from small, cold-water springs fed by groundwater during the rainy season. Because of climate change, drastic changes in annual African rainfall threaten many of these rural communities that depend on the replenishment of springs during the rainy season [6]. To begin to solve some issues that accompany limited access to fresh, clean water (poverty, malnourishment, water-borne disease, etc.), it is necessary to begin to record and analyze the water quality of rural water to empower local communities to retain high water quality [5]. This project combines water chemistry data and diatom assemblage analysis to understand water quality and pollution on the Humpata Plateau in an effective and simple manner that can embolden communities to protect their water resources.

Diatoms are siliceous microalga frequently used to identify and reconstruct changes in lake chemistry and water quality related to climate change or anthropogenic pollution [7-10]. Diatom ecology provides environmental information because each taxon has specific preferences for certain physical (temperature, light, turbulence, etc.) and chemical ( $\mathrm{pH}$, dissolved organic carbon, nutrients, salinity, etc.) parameters [8]. Physical parameters are often difficult to deduce as they impact chemical parameters and cannot be dissociated from other variables $[8,11,12]$. Diatom analyses, therefore, focus on the reconstruction and interpretation of chemical parameters (particularly $\mathrm{pH}$, conductivity, and pollutants), which are more readily discernible. Diatoms are strong water-quality indicators because of (1) their sensitivity to changes in water chemistry, (2) their numerical abundance in both past and modern sediments, (3) their siliceous frustules, which can withstand some dissolution post-deposition, (4) their rapid response to changing variables as primary producers, and (5) the large geographic ranges of some taxa, although recent studies show that many species may not be as cosmopolitan as previously suspected and instead represent similar morphotypes [13-15]. Therefore, collecting diatoms with relevant water chemistry data can be extremely valuable in discerning water quality and environmental change.

This research focuses on determining diatom taxa on the Humpata Plateau in southwestern Angola to understand how they relate to local hydrochemistry and anthropogenic pollution from agricultural and excremental waste. It aims to act as a guide for future studies in rural regions of Africa where resources are scarce, and travel is difficult, to continually monitor chemical changes. Specifically, the objectives of this study are to:

1. Record modern diatom assemblages at five sites in southwestern Angola.

2. Determine which hydrochemical variables diatom communities can estimate for local water bodies.

3. Identify potential human impact on water through differences in water quality and diatom assemblages.

\section{Geologic and Climatic Setting}

\subsection{Geography and Geology}

As Africa's seventh largest country, Angola, located in southwestern Africa (Figure 1A), displays drastically varied geologies, landscapes, and climates [16]. In southwestern Angola, the dry subhumid Humpata Plateau extends over $300 \mathrm{~km}$ east and west and reaches an elevation of $2300 \mathrm{~m}[3,17]$ (Figure 1B). The Province of Huíla, where the Humpata Plateau is located, has an area of $78,879 \mathrm{~km}^{2}$ with a population of around 2.6 million people, with the majority of the population surrounding the province's capital city, Lubango [18]. The Plateau is made of a Proterozoic craton overlain by the Chela Group, a $600 \mathrm{~m}$ thick volcanic sedimentary sequence deposited between 1.947 and $1.810 \mathrm{Ga}$ (Figure 1C) [17-21]. The top layer of the Chela Group, called the Leba Formation, is composed of layers of greyishblue dolomitic limestone scattered with stromatolites, argillites (lightly metamorphosed mudstone), and chert (Figure 1D) [18]. The Leba Formation unconformably lies over the Cangalongue Formation, which is composed of interbedded red sandstones, red shales, limestones, and siltstones [21]. The calcite-rich bedrock contains karst features including caves and springs which have been associated with paleontological and archaeological 
finds [22]. The soils on the Humpata Plateau consist mainly of leptosols (shallow, gravelly soils) and ferralsols (heavily weathered and iron and aluminum rich red/yellow soils), both of which have low fertility [16].
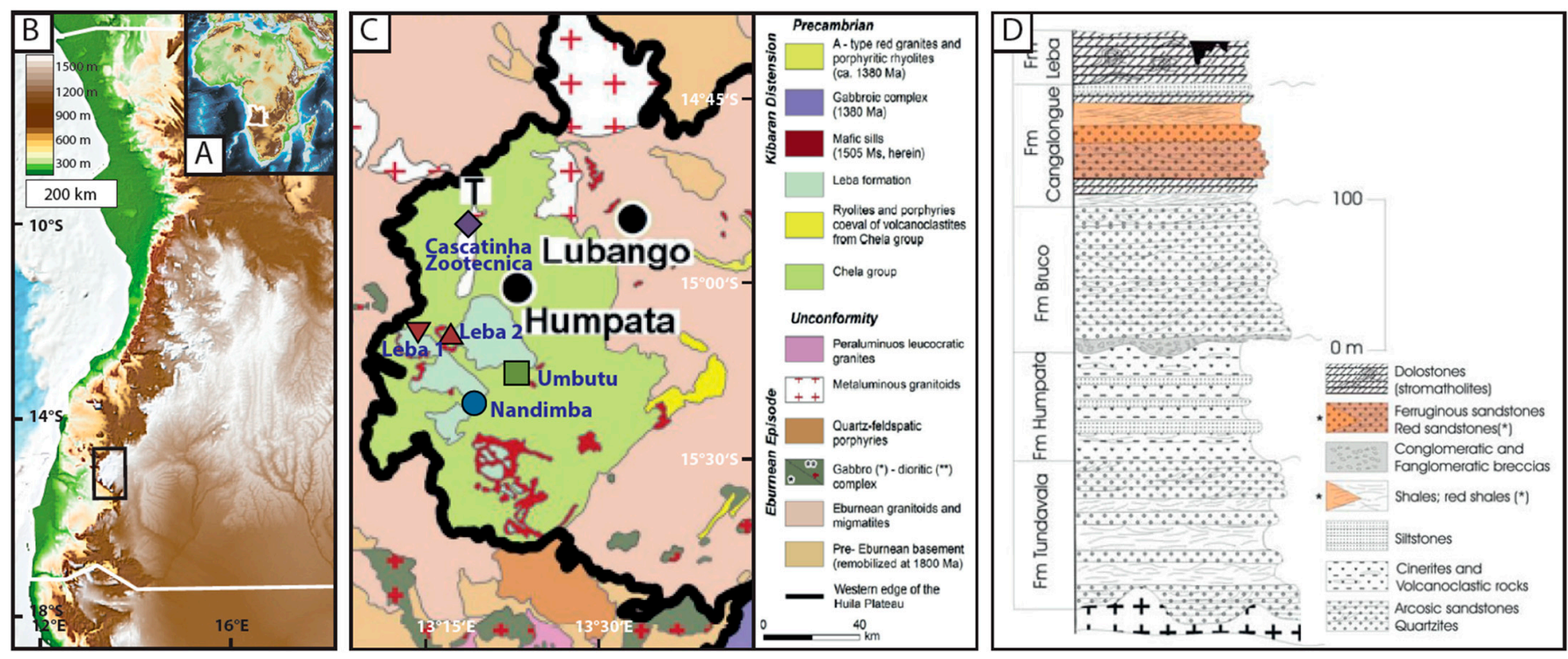

Figure 1. (A) Topographic map of Africa with Angola outlined in white. (B) Topographic map of western Angola with the study area outlined with a black box. (C) A close-up of the bedrock at the edge of the Humpata Plateau (Modified from Lopes et al., 2019) [18]. Sites from this study are added to the map and are located on the Leba Formation, Chela Group, or metaluminous granitoid. (D) A cross-section of the Chela Group, including the Leba and Cangalongue Formations on the Humpata Plateau (From Pereira et al., 2011) [21]. Asterisks $\left(^{*}\right)$ denote the shading for red shales and red sandstones.

\subsection{Seasonality and Climate}

The seasons in southwestern Angola are dominated by yearly fluctuations in precipitation rather than temperature, with a warmer/rainy season from the end of September until May and a cooler/dry season from the end of May until September [3]. Ninety-five percent of annual rainfall across Angola occurs during the wet season [23]. From the Humpata weather gauge located at $15.069^{\circ} \mathrm{S}$ and $13.251^{\circ} \mathrm{E}$ at an altitude of $1880 \mathrm{~m}$, average monthly temperatures from 2015 to 2018 range, inclusively, from a dry season average of $15.5^{\circ} \mathrm{C}$ to a wet season average of $18.2^{\circ} \mathrm{C}$, with a four-year annual average of $17.3^{\circ} \mathrm{C}$ [24]. In contrast, precipitation varies, inclusively, from a dry season average of $0.35 \mathrm{~mm}$ of rain per month to a wet season average of $136 \mathrm{~mm}$ of rain per month [24]. Annual precipitation varies slightly across the sampled sites. Based on data from the Climate Change Knowledge Portal, across the sampling sites, average annual precipitation from 1910 to 1998 varies from Cascatinha da Zootécnica at $570 \mathrm{~mm} /$ year to Nandimba Tchivinguiro at $498 \mathrm{~mm} /$ year [25]. Since the 1930s, this area has seen a decrease in rainfall, although data is fragmented [6,25]. The decadal averages for Cascatinha da Zootécnica and Nandimba Tchivinguiro from the 1930s to $1970 \mathrm{~s}$ range from $609-812 \mathrm{~mm} /$ year and $523-680 \mathrm{~mm} /$ year, respectively [25]. In contrast, the average for Cascatinha da Zootécnica and Nandimba Tchivinguiro, respectively, were 477 and $407 \mathrm{~mm} /$ year in the 1980s and 446 and $395 \mathrm{~mm} /$ year in the 1990s [25]. Unfortunately, scarce data since 1998 reduce the ability to further analyze how current rainfall patterns differ, although local communities stress that water availability has decreased in recent memory [Personal Communication, Field Season 2019].

Rainfall in southwestern Angola is controlled by sea surface temperatures, specifically the Benguela Current, and air masses including high- and low-pressure systems that move seasonally over southern Africa. The cold Benguela Current, which moves northward along the western coast of southern Africa to about $15^{\circ} \mathrm{S}$ (shifting seasonally between $14^{\circ} \mathrm{S}$ and $16^{\circ} \mathrm{S}$ ), dictates rainfall patterns along Angola's coast by decreasing moisture availability and transport [26]. High-pressure systems lead to fair weather conditions and 
include the South Atlantic Anticyclone and the South Indian Anticyclone, which make landfall during the austral winter [27]. Low-pressure systems that create wet conditions include the Angola Low and Tropical Temperate Trough and develop over southern Angola during the austral summer. Larger low-pressure systems that affect southwestern Angolan rainfall include the Intertropical Convergence Zone and the Congo Air Boundary [26]. The Intertropical Convergence Zone reflects the amount of solar insolation received by the atmosphere and Earth's surface, leading to a band of low pressure near the equator, which draws in moisture and rainfall [27]. The Congo Air Boundary is the area of convergence of airmasses derived from the South Atlantic and Indian Oceans, bringing moisture over southern Africa and resulting in rainfall [27]. Larger global phenomenon including the Atlantic Walker Cell and El Niño events likely contribute to Angolan rainfall through time, although their impacts are not well understood [28].

\subsection{Hydrological Setting}

The southwestern part of the Humpata Plateau is located within the Cunene (or Kunene) Basin. The Cunene River represents the confluence of water within the basin. The Cunene River starts within the highlands near Huambo at $12.8^{\circ} \mathrm{S}, 15.7^{\circ} \mathrm{E}$, creates the border between Angola and Namibia, and drains into the Atlantic Ocean at Foz da Cunene where discharge is about $15 \mathrm{~km}^{3} /$ year [29]. Mean annual runoff of the Cunene Basin is 5500 million $\mathrm{m}^{3} /$ year [30]. With $60 \%$ of Angolan territory located at an altitude between 1000 and $2000 \mathrm{~m}$ [23], Angola acts as the "water tower" of southern and central Africa [16]. The Cunene Basin is located next to the Okavango Basin in the east and the Cuvelai Basin in the south, which both feed into two of Africa's largest wetlands, the Kalahari and Etosha, respectively [16]. The current barrier between the Cunene and Cuvelai Basins is only a few meters in elevation, but sufficient to prevent Cunene flooding from flowing into the Cuvelai System [31,32]. Nonetheless, the three basins are likely connected hydraulically underground [31]. International disagreements related to use and control of the Cunene River's water have resulted because these systems provide access to potable water for populations throughout the region [29].

\section{Materials and Methods}

\subsection{Sample Collection}

Samples were collected during the dry season in July 2019 from four water bodies including cold springs (Umbutu and Nandimba Tchivinguiro), a river (Leba), and a waterfall pool (Cascatinha da Zootécnica) (Figure 2). Sites for sampling were found by searching for bodies of water on Google Earth and communicating with local people about small springs in the area. A Hanna multi-parameter probe HI98194 was used to collect data on temperature $\left({ }^{\circ} \mathrm{C}\right)$, conductivity $(\mu \mathrm{S} / \mathrm{cm}), \mathrm{pH}$, and Total Dissolved Solids (TDS; ppm) (Table 1). Alkalinity ( $\mathrm{mg} / \mathrm{L}$ solution as $\mathrm{CaCO}_{3}$ ) was estimated using alkalinity strips.

Water samples were collected using a syringe with a $0.45 \mu \mathrm{m}$ filter. Samples for cation and anion analyses were collected from $60 \mathrm{~mL}$ water samples. Additionally, cation samples were acidified with $0.6 \mathrm{~mL}$ of $65 \% \mathrm{HNO}_{3}$ to ensure cations would not precipitate out of solution. Cation and anion samples were sent to the Petrology and Mineralogy Raw Materials lab at the Universität Tübingen for analysis where they were analyzed using ion chromatography compact IC Flex and Compact IC Plus from Metrohm.

Diatom samples were collected from standing water, plants, sediments, and rocks, according to the recommendations of Kelly et al. (2001) [33]. Standing water samples were collected by retrieving $20 \mathrm{~mL}$ of surface water, although this did not yield enough diatoms and is therefore not considered further in this paper. Multiple macrophytes located in direct sunlight were selected for epiphytic sampling. Sediment samples were scooped from about a meter offshore, with muds (epipelon) and sands/small rocks (episammon) collected separately. Larger rocks (epilithic) were scrubbed with a clean toothbrush. Distilled water was used to clean the toothbrush onto a tray which was then transferred into a sample container. All diatom samples were treated in the field with Lugol's solution. 


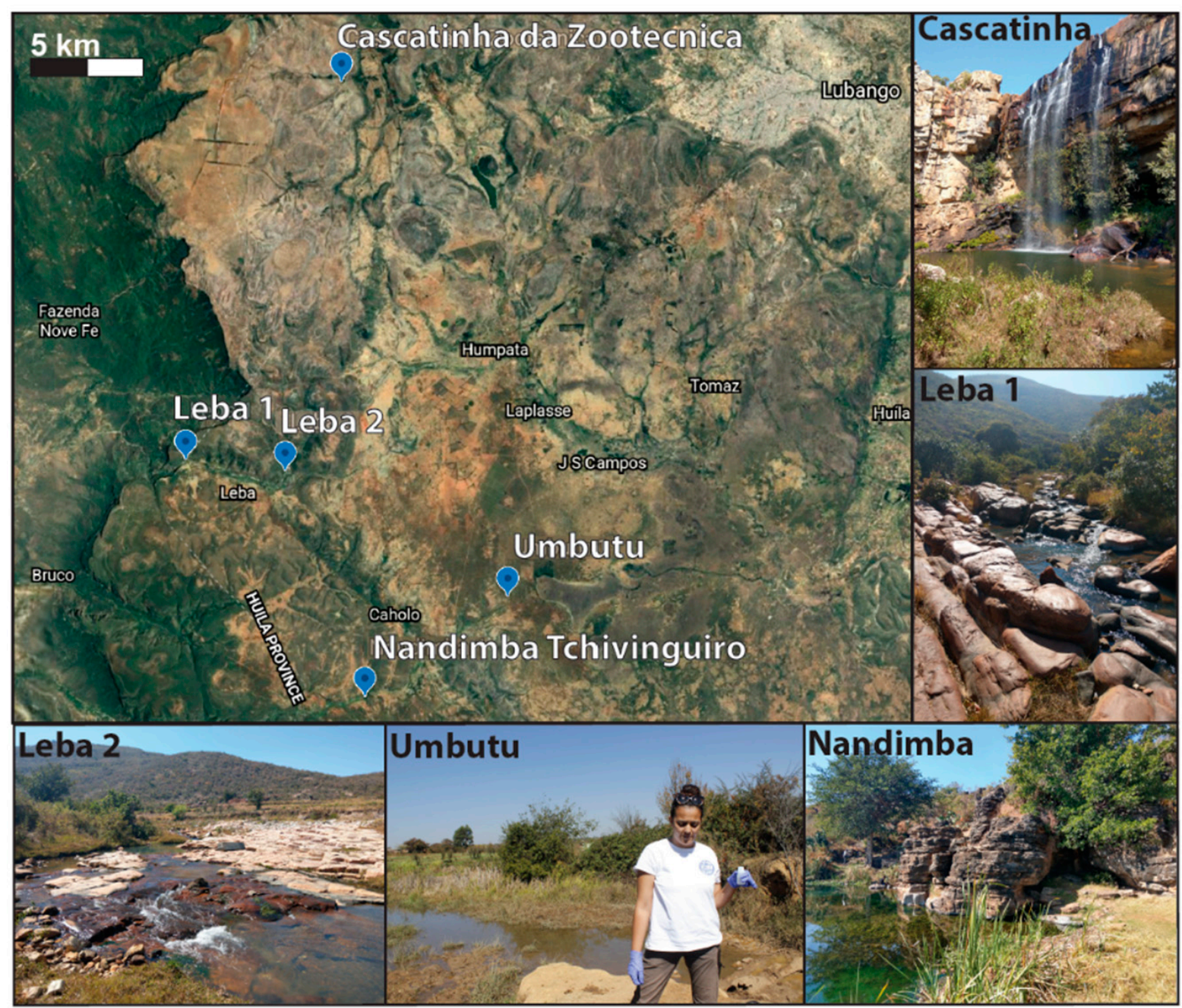

Figure 2. Satellite image from Google Earth of the sampled sites. A field photo from each site is included.

Table 1. Collected and calculated physical and chemical parameters of the sites including water temperature (Temp.), $\mathrm{pH}$, conductivity (Cond.), alkalinity (Alk.), Total Dissolved Solids (TDS), and major cations and anions. Measurements with an asterisk $\left.{ }^{*}\right)$ were calculated using Geochemist Workbench.

\begin{tabular}{|c|c|c|c|c|c|c|c|c|c|c|c|c|c|c|}
\hline Sites & $\begin{array}{l}\text { Lat. } \\
\left({ }^{\circ} \mathrm{S}\right)\end{array}$ & $\begin{array}{l}\text { Long. } \\
\left({ }^{\circ} \mathbf{E}\right)\end{array}$ & $\begin{array}{l}\text { Elevation } \\
(\mathrm{m})\end{array}$ & \multicolumn{2}{|c|}{$\begin{array}{c}\text { Water Body } \\
\text { Type }\end{array}$} & \multicolumn{2}{|c|}{ Water Type } & $\begin{array}{l}\text { Temp. } \\
\left({ }^{\circ} \mathrm{C}\right)\end{array}$ & $\mathrm{pH}$ & $\begin{array}{l}\text { Cond. } \\
(\mu \mathrm{S} / \mathrm{cm})\end{array}$ & \multicolumn{2}{|c|}{$\begin{array}{l}\text { * Alk. }\left(\mathrm{mg} / \mathrm{L} \mathrm{sol}^{\prime} \mathrm{n}\right. \\
\left.\text { as } \mathrm{CaCO}_{3}\right)\end{array}$} & \multicolumn{2}{|c|}{ TDS (ppm) } \\
\hline $\begin{array}{l}\text { Cascatinha da } \\
\text { Zootécnica } 1\end{array}$ & 14.9166 & 13.3114 & 1670 & \multicolumn{2}{|c|}{ Waterfall Pool } & \multicolumn{2}{|c|}{$\mathrm{Na}-\mathrm{Cl}$} & 14.22 & 8.26 & 17 & \multicolumn{2}{|c|}{1} & \multicolumn{2}{|c|}{8} \\
\hline $\begin{array}{c}\text { Nandimba } \\
\text { Tchivinguiro } 1\end{array}$ & 15.1675 & 13.3207 & 1677 & \multicolumn{2}{|c|}{ Cold Spring } & \multicolumn{2}{|c|}{$\mathrm{Mg}-\mathrm{HCO}_{3}$} & 22.12 & 7.35 & 186 & \multicolumn{2}{|c|}{147} & \multicolumn{2}{|c|}{186} \\
\hline Umbutu 1 & 15.1263 & 13.3815 & 1806 & \multicolumn{2}{|c|}{ Cold Spring } & \multicolumn{2}{|c|}{$\mathrm{Mg} / \mathrm{Ca}-\mathrm{HCO}_{3}$} & 22.18 & 7.16 & 1035 & \multicolumn{2}{|c|}{47} & \multicolumn{2}{|c|}{520} \\
\hline Leba 1 & 15.0704 & 13.2240 & 1689 & \multicolumn{2}{|c|}{ River } & \multicolumn{2}{|c|}{$\mathrm{Ca} / \mathrm{Mg}-\mathrm{HCO}_{3}$} & 14.84 & 7.92 & 95 & \multicolumn{2}{|c|}{16} & \multicolumn{2}{|c|}{40} \\
\hline Leba 2 & 15.0749 & 13.2868 & 1730 & \multicolumn{2}{|c|}{ River } & \multicolumn{2}{|c|}{$\mathrm{Na} / \mathrm{Ca}-\mathrm{HCO}_{3} / \mathrm{Cl}$} & 17.80 & 7.75 & 34 & \multicolumn{2}{|c|}{2} & \multicolumn{2}{|c|}{13} \\
\hline Sites & $\begin{array}{c}\mathrm{Li}^{+} \\
(\mathrm{mg} / \mathrm{L})\end{array}$ & $\begin{array}{c}\mathrm{Na}^{+} \\
(\mathrm{mg} / \mathrm{L})\end{array}$ & $\begin{array}{c}\mathrm{K}^{+} \\
(\mathrm{mg} / \mathrm{L})\end{array}$ & $\begin{array}{l}\mathrm{Ca}^{2+} \\
(\mathrm{mg} / \mathrm{L})\end{array}$ & $\begin{array}{c}\mathrm{Mg}^{2+} \\
(\mathrm{mg} / \mathrm{L})\end{array}$ & $\begin{array}{c}\mathrm{Sr}^{2+} \\
(\mathrm{mg} / \mathrm{L})\end{array}$ & $\begin{array}{c}{ }^{*} \mathrm{HCO}_{3}- \\
(\mathrm{mg} / \mathrm{L})\end{array}$ & $\begin{array}{l}\mathrm{F}^{-} \\
(\mathrm{mg} / \mathrm{L})\end{array}$ & $\begin{array}{l}\mathrm{Cl}^{-} \\
(\mathrm{mg} / \mathrm{L})\end{array}$ & $\begin{array}{l}\mathrm{Br}^{-} \\
(\mathrm{mg} / \mathrm{L})\end{array}$ & $\begin{array}{l}\mathrm{NO}_{3}^{-} \\
(\mathrm{mg} / \mathrm{L})\end{array}$ & $\begin{array}{l}\mathrm{PO}_{4}{ }^{3-} \\
(\mathrm{mg} / \mathrm{L})\end{array}$ & $\begin{array}{l}\mathrm{SO}_{4}{ }^{2-} \\
(\mathrm{mg} / \mathrm{L})\end{array}$ & $\begin{array}{c}\mathrm{I}^{-} \\
(\mathrm{mg} / \mathrm{L})\end{array}$ \\
\hline $\begin{array}{l}\text { Cascatinha da } \\
\text { Zootécnica } 1\end{array}$ & 0.00 & 0.60 & 0.25 & 0.11 & 0.06 & 0.00 & 0.83 & 0.01 & 0.64 & 0.01 & 0.16 & 0.01 & 0.06 & 0.01 \\
\hline $\begin{array}{c}\text { Nandimba } \\
\text { Tchivinguiro } 1\end{array}$ & 0.00 & 2.20 & 1.40 & 28.00 & 19.00 & 0.00 & 176.20 & 0.22 & 4.20 & 0.03 & 0.89 & 0.06 & 0.71 & 0.01 \\
\hline Umbutu 1 & 0.00 & 1.30 & 0.90 & 9.20 & 5.60 & 0.00 & 57.47 & 0.08 & 1.00 & 0.01 & 0.89 & 0.20 & 0.34 & 0.06 \\
\hline Leba 1 & 0.01 & 2.10 & 0.48 & 3.10 & 1.50 & 0.07 & 19.64 & 0.02 & 1.70 & 0.00 & 0.01 & 0.01 & 0.53 & 0.01 \\
\hline Leba 2 & 0.00 & 0.87 & 0.51 & 0.35 & 0.13 & 0.00 & 1.96 & 0.01 & 1.10 & 0.00 & 0.49 & 0.01 & 0.34 & 0.01 \\
\hline
\end{tabular}




\subsection{Diatom Preparation and Identification}

All samples not already suspended in water were washed with distilled water using a 210 micrometer sieve. The $<210 \mu \mathrm{m}$ samples were decanted using a centrifuge for five minutes at 2500 revolutions per minute (RPM) to decrease the volume to five $\mathrm{mL}$. Samples were prepared using a modified hot $\mathrm{H}_{2} \mathrm{O}_{2}$ method [34]. Each sample was heated at $90{ }^{\circ} \mathrm{C}$ with $20 \mathrm{~mL}$ of $30 \% \mathrm{H}_{2} \mathrm{O}_{2}$ until the majority had evaporated (four to five hours) to remove the organics. A few drops of $10 \% \mathrm{HCl}$ (to remove carbonates) and a Lycopodium spore (to measure concentration for use in future studies) were added to sit for about $24 \mathrm{~h}$. Samples were transferred to $15 \mathrm{~mL}$ centrifuge tubes using distilled water and centrifuged for five minutes at 2500 RPM and decanted-a process that was repeated four times to wash off remaining acids. Once this process was finished, one drop of ammonium hydroxide was added to separate the aggregates and remove clays. The sample was centrifuged and decanted a final time at 2500 RPM for five minutes. The sample was adjusted with an appropriate amount of deionized water (given the anticipated concentration of the sample) and added to the coverslip to dry in a dust-free shelf for $24 \mathrm{~h}$. Once the coverslip was dry, Naphrax was used to adhere the cover slip to a glass slide and heated at $125^{\circ} \mathrm{C}$ until the Naphrax was cured (about $20 \mathrm{~min}$ ). Prepared and unprepared samples are located at the University of Tübingen.

When possible, at least 400 diatom valves were counted on an Olympus BX50 light microscope at $1000 \times$ magnification with a 700D Canon Camera attached to take photos of taxa (Figure S1). The presence of extremely small taxa $(<5 \mu \mathrm{m})$ indicates samples were not biased towards larger taxa during sample preparation. All planktonic and some epilithic samples could not be included because there were too few specimens in the sample. Identification was conducted using Gasse (1986), Cocquyt (1998), Taylor et al. (2007a), and Spaulding et al. (2020) [35-38]. A valve was counted as one if more than $50 \%$ of the valve was visible and identifiable. In all cases, specimens were identified to the highest taxonomic level as accurately as possible (Table 2; Table S1). Light microscope identification was supplemented with Scanning Electron Microscope photos taken at the Microfossils Laboratory in the Department of Geosciences of the Eberhard Karls Universität Tübingen with a Phenom XL Scanning Electron Microscope (Figures 3 and 4). The electron source is a Cerium Hexaborit (CeB6) cathode. Samples were coated with $70 \mathrm{~nm}$ gold and analyzed with a Back Scatter Detector (BSD) with $15 \mathrm{kV}$ acceleration voltage.

\subsection{Analytical Methods}

Hydrochemistry of the water bodies was analyzed using Geochemist Workbench (GWB). Given the remote location of this work, well-constrained alkalinity and $\mathrm{HCO}_{3}{ }^{-}$ measurements were not possible. Alkalinity strips were used to estimate alkalinity in the field and reflect the trends calculated by GWB. GWB was used balance the ions using $\mathrm{HCO}_{3}{ }^{-}$. Given the abundance of $\mathrm{Ca}^{2+}$ in the bedrock, such assumptions are likely valid and provide reasonable results that allow for better analysis of the data [39]. Water body type was determined according to USGS water quality standards where a dominant ion represents $50 \%$ of total ions measured in $\mathrm{mEq} / \mathrm{L}$ [40]. If no ion represented $50 \%$, the top two ions were used in descending order. 


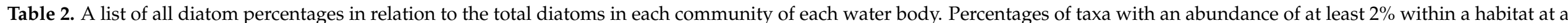

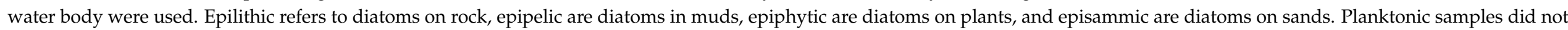
yield enough diatoms to reach the 400-valve minimum and are therefore not included in this study. Planktonic counts can be found in Table S1.

\begin{tabular}{|c|c|c|c|c|c|c|c|c|c|c|c|c|c|c|c|c|c|c|c|c|c|}
\hline$\stackrel{\text { ثे }}{*}$ & 总 & 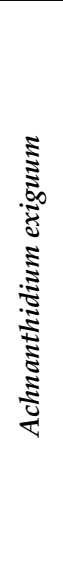 & 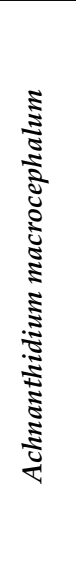 & 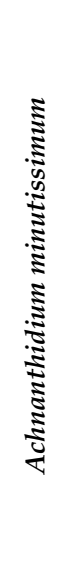 & 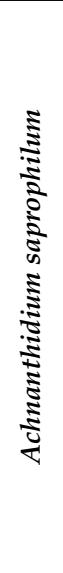 & 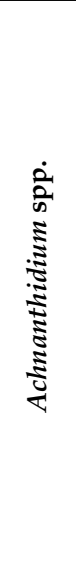 & 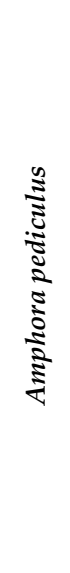 & 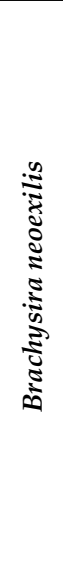 & 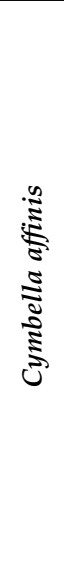 & 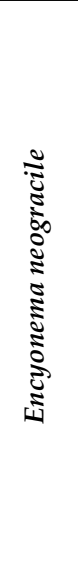 & 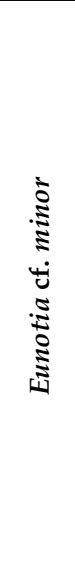 & 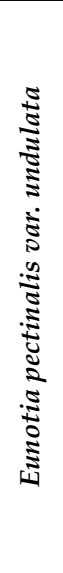 & 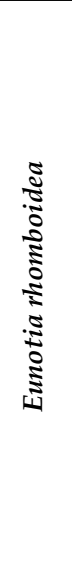 & 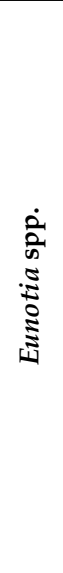 & 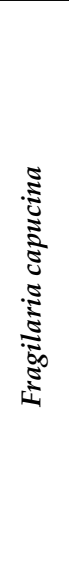 & 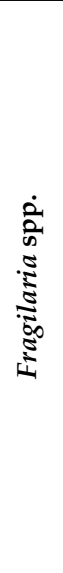 & 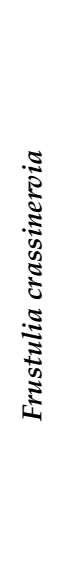 & 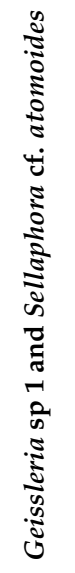 & 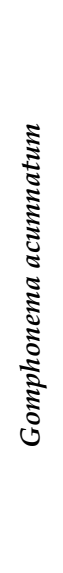 & 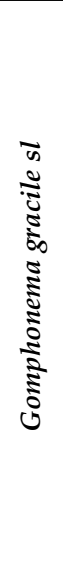 & 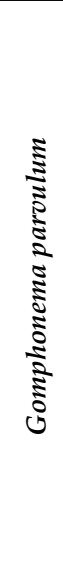 \\
\hline Cascatinha da Zootécnica 1 & $\begin{array}{l}\text { Epithlithic } \\
\text { Epipelic } \\
\text { Epiphytic }\end{array}$ & & $\begin{array}{l}12.9 \\
11.6 \\
15.1\end{array}$ & $\begin{array}{l}0.2 \\
2.1\end{array}$ & $\begin{array}{l}9.7 \\
2.9\end{array}$ & $\begin{array}{l}3.2 \\
4.3 \\
9.9\end{array}$ & & $\begin{array}{l}3.4 \\
7.7\end{array}$ & $\begin{array}{l}0.2 \\
1.0\end{array}$ & $\begin{array}{c}10.9 \\
5.4\end{array}$ & $\begin{array}{c}6.5 \\
6.3 \\
11.6\end{array}$ & $\begin{array}{l}4.8 \\
3.1\end{array}$ & $\begin{array}{c}9.7 \\
15.6 \\
11.8\end{array}$ & 0.2 & & $\begin{array}{l}6.5 \\
0.8\end{array}$ & 0.9 & & & $\begin{array}{l}2.7 \\
7.2\end{array}$ & $\begin{array}{l}3.2 \\
2.3 \\
4.8\end{array}$ \\
\hline Nandimba Tchivinguiro 1 & $\begin{array}{c}\text { Epilithic } \\
\text { Epipelic } \\
\text { Epiphytic } \\
\text { Episammic }\end{array}$ & $\begin{array}{l}0.2 \\
0.2 \\
\\
0.1 \\
\end{array}$ & & $\begin{array}{l}12.1 \\
2.2 \\
12.7 \\
2.8 \\
\end{array}$ & $\begin{array}{l}0.7 \\
5.3\end{array}$ & 3.6 & $\begin{array}{l}0.9 \\
0.4 \\
2.0 \\
\end{array}$ & 1.3 & $\begin{array}{l}1.3 \\
0.8 \\
0.6\end{array}$ & 1.1 & $\begin{array}{l}0.2 \\
1.1 \\
5.9\end{array}$ & 0.2 & & $\begin{array}{l}0.9 \\
0.8\end{array}$ & & & & $\begin{array}{c}0.2 \\
4.2 \\
2.9 \\
26.1\end{array}$ & & $\begin{array}{l}0.9 \\
0.2 \\
0.2\end{array}$ & $\begin{array}{l}3.4 \\
0.3 \\
6.4\end{array}$ \\
\hline Umbutu 1 & $\begin{array}{l}\text { Epithlithic } \\
\text { Epipelic } \\
\text { Epiphytic }\end{array}$ & $\begin{array}{l}0.5 \\
2.6 \\
0.5\end{array}$ & & $\begin{array}{l}24.2 \\
20.8 \\
10.6\end{array}$ & $\begin{array}{l}1.9 \\
2.6 \\
2.7\end{array}$ & $\begin{array}{l}23.0 \\
1.8 \\
6.9\end{array}$ & & $\begin{array}{l}3.4 \\
5.1 \\
9.4\end{array}$ & $\begin{array}{l}2.8 \\
0.7\end{array}$ & 0.5 & 0.2 & 0.2 & 0.3 & 0.5 & & 4.6 & $\begin{array}{l}3.4 \\
0.5\end{array}$ & & $\begin{array}{l}7.2 \\
6.7\end{array}$ & & $\begin{array}{l}24.0 \\
10.5 \\
18.2\end{array}$ \\
\hline Leba 1 & $\begin{array}{c}\text { Epilithic } \\
\text { Epipelic } \\
\text { Epiphytic } \\
\text { Episammic }\end{array}$ & $\begin{array}{l}0.8 \\
0.9 \\
3.8\end{array}$ & 2.5 & $\begin{array}{l}33.2 \\
29.9 \\
40.3 \\
26.4\end{array}$ & $\begin{array}{l}1.7 \\
1.3\end{array}$ & $\begin{array}{c}5.9 \\
11.2 \\
14.6 \\
6.4\end{array}$ & & $\begin{array}{l}0.2 \\
0.4\end{array}$ & $\begin{array}{l}0.4 \\
0.2 \\
1.1 \\
2.0\end{array}$ & $\begin{array}{l}0.4 \\
0.2 \\
0.5 \\
0.2\end{array}$ & $\begin{array}{l}0.8 \\
1.5 \\
\\
0.4\end{array}$ & $\begin{array}{l}1.5 \\
0.4\end{array}$ & $\begin{array}{l}0.2 \\
0.5 \\
1.1\end{array}$ & $\begin{array}{l}0.2 \\
0.4\end{array}$ & $\begin{array}{l}4.2 \\
1.9 \\
0.9 \\
0.4\end{array}$ & $\begin{array}{l}0.4 \\
1.8 \\
2.2\end{array}$ & 0.2 & & 0.7 & $\begin{array}{l}2.1 \\
\\
0.9 \\
0.2\end{array}$ & $\begin{array}{l}3.8 \\
2.1 \\
2.3 \\
2.9\end{array}$ \\
\hline Leba 2 & $\begin{array}{c}\text { Epilithic } \\
\text { Epipelic } \\
\text { Epiphytic } \\
\text { Episammic }\end{array}$ & 0.2 & $\begin{array}{c}11.4 \\
15.6 \\
8.0 \\
25.4\end{array}$ & $\begin{array}{l}2.6 \\
2.0 \\
0.5 \\
8.8\end{array}$ & 1.6 & $\begin{array}{c}4.0 \\
0.4 \\
9.0 \\
14.0\end{array}$ & & $\begin{array}{l}1.4 \\
7.1 \\
3.6\end{array}$ & 0.4 & $\begin{array}{l}0.8 \\
3.1 \\
0.2\end{array}$ & $\begin{array}{l}4.4 \\
2.8 \\
6.1 \\
1.2\end{array}$ & $\begin{array}{l}0.7 \\
\\
0.2 \\
1.7\end{array}$ & $\begin{array}{l}2.6 \\
0.8 \\
6.8 \\
6.7\end{array}$ & $\begin{array}{l}2.2 \\
7.1 \\
2.6\end{array}$ & & $\begin{array}{l}5.7 \\
2.6\end{array}$ & 0.4 & & & $\begin{array}{l}0.2 \\
1.0\end{array}$ & $\begin{array}{c}19.3 \\
1.8 \\
2.6 \\
2.1\end{array}$ \\
\hline
\end{tabular}


Table 2. Cont.

\begin{tabular}{|c|c|c|c|c|c|c|c|c|c|c|c|c|c|c|c|c|c|c|c|c|c|c|c|}
\hline 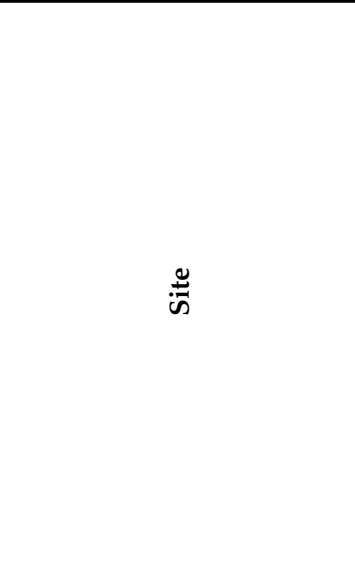 & 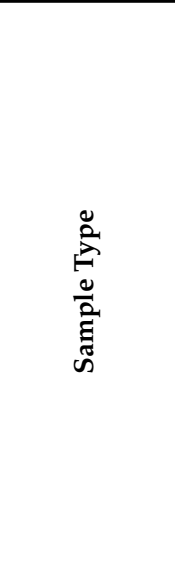 & 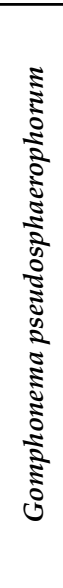 & 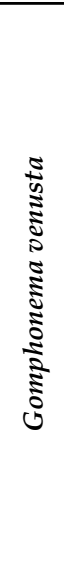 & 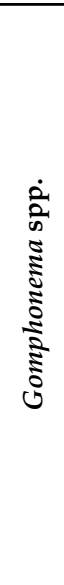 & 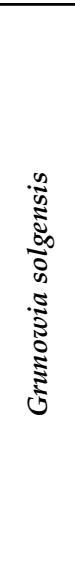 & 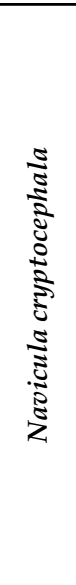 & 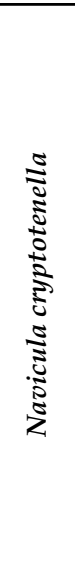 & 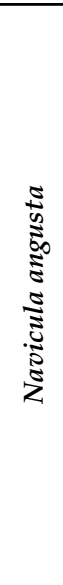 & 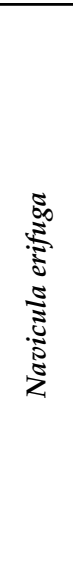 & 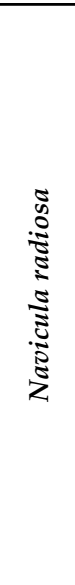 & 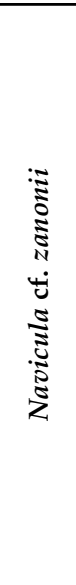 & 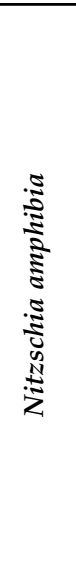 & 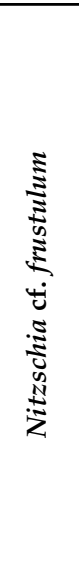 & 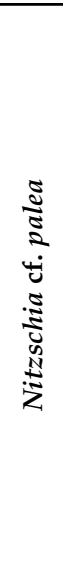 & 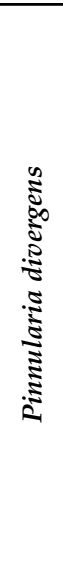 & 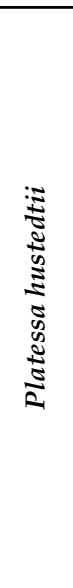 & 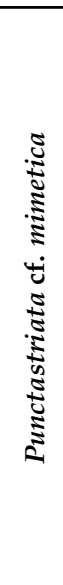 & 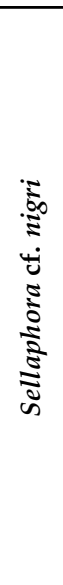 & 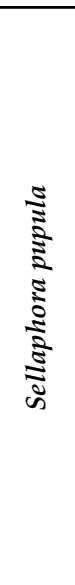 & 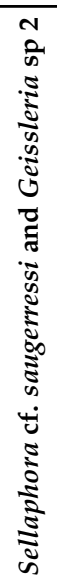 & 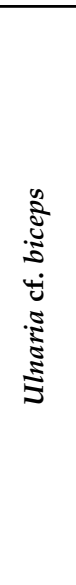 & 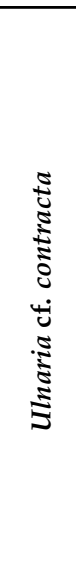 & 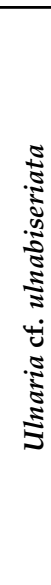 \\
\hline \multirow{3}{*}{ Cascatinha da Zootécnica 1} & Epithlithic & & 9.7 & & 6.5 & 19.4 & 6.5 & & & & & & 6.5 & & & & & & & & & & \\
\hline & Epipelic & & & 3.6 & & 21.5 & 0.5 & 2.5 & & & & & 0.2 & 0.2 & 0.2 & & & & & & & & \\
\hline & Epiphytic & 1.9 & & 2.9 & 0.2 & 8.5 & & 0.2 & & & & & 0.2 & & 0.2 & & & & & & & & 0.2 \\
\hline \multirow{2}{*}{ Nandimba Tchivinguiro 1} & Epilithic & & 0.2 & & 2.9 & 2.9 & 0.2 & & 39.8 & & & 14.6 & 3.6 & 0.4 & & 1.3 & 1.1 & & & & 0.1 & 2.5 & 0.2 \\
\hline & Episammon & & 0.1 & & 23.3 & & & & 1.8 & & 0.7 & 12.2 & 12.2 & 0.9 & & 1.8 & 0.3 & 5.1 & & 9.5 & & & \\
\hline \multirow{3}{*}{ Umbutu 1} & Epithlithic & & & & & 1.7 & 11.3 & & & 0.2 & & 2.9 & & & 0.7 & 0.2 & & & 1.7 & & & & \\
\hline & Epipelic & & & 0.5 & & 1.3 & 1.0 & & & 14.4 & & 0.5 & 1.3 & 2.6 & 2.1 & & & & 10.5 & & 0.5 & & 0.3 \\
\hline & Epiphytic & & & 4.7 & & 6.4 & 2.2 & & & 11.8 & & & & 2.0 & 1.0 & & & & 10.3 & & 0.4 & 0.2 & 0.4 \\
\hline \multirow{4}{*}{ Leba 1} & Epilithic & & 0.4 & & & & & & & 22.3 & & & 5.9 & 0.4 & 0.4 & & & & & 0.4 & 12.8 & & 4.8 \\
\hline & Epipelic & & 1.5 & & & & 1.7 & & & 36.9 & & 0.6 & & & & & & & & & 0.1 & & 1.2 \\
\hline & Epiphytic & & 3.6 & & & & 0.5 & & & 23.9 & & 2.0 & & 0.2 & & & & & & & 0.8 & & 0.6 \\
\hline & Episammon & & 5.3 & & 0.2 & & 0.2 & & & 40.2 & & & & & & & & & 0.4 & 0.2 & 1.1 & 0.7 & 1.0 \\
\hline \multirow{4}{*}{ Leba 2} & Epilithic & 2.6 & & 20.0 & & & & & & 4.4 & 17.8 & & 0.4 & & 0.2 & & 0.2 & & & & 0.7 & 6.2 & 0.9 \\
\hline & Epipelic & 0.8 & 0.6 & & & 0.8 & & & & 6.4 & 49.1 & & & & & & & & 0.2 & & 0.4 & 8.0 & 0.5 \\
\hline & Epiphytic & 0.9 & & 1.9 & & 1.4 & 0.2 & & & 1.9 & 17.0 & & & 0.2 & & & & & & & 0.1 & 17.2 & 0.2 \\
\hline & Episammon & 0.5 & & & & 0.2 & 1.7 & & & 1.0 & 15.7 & 0.2 & & & & & & & & & & 9.3 & 0.2 \\
\hline
\end{tabular}




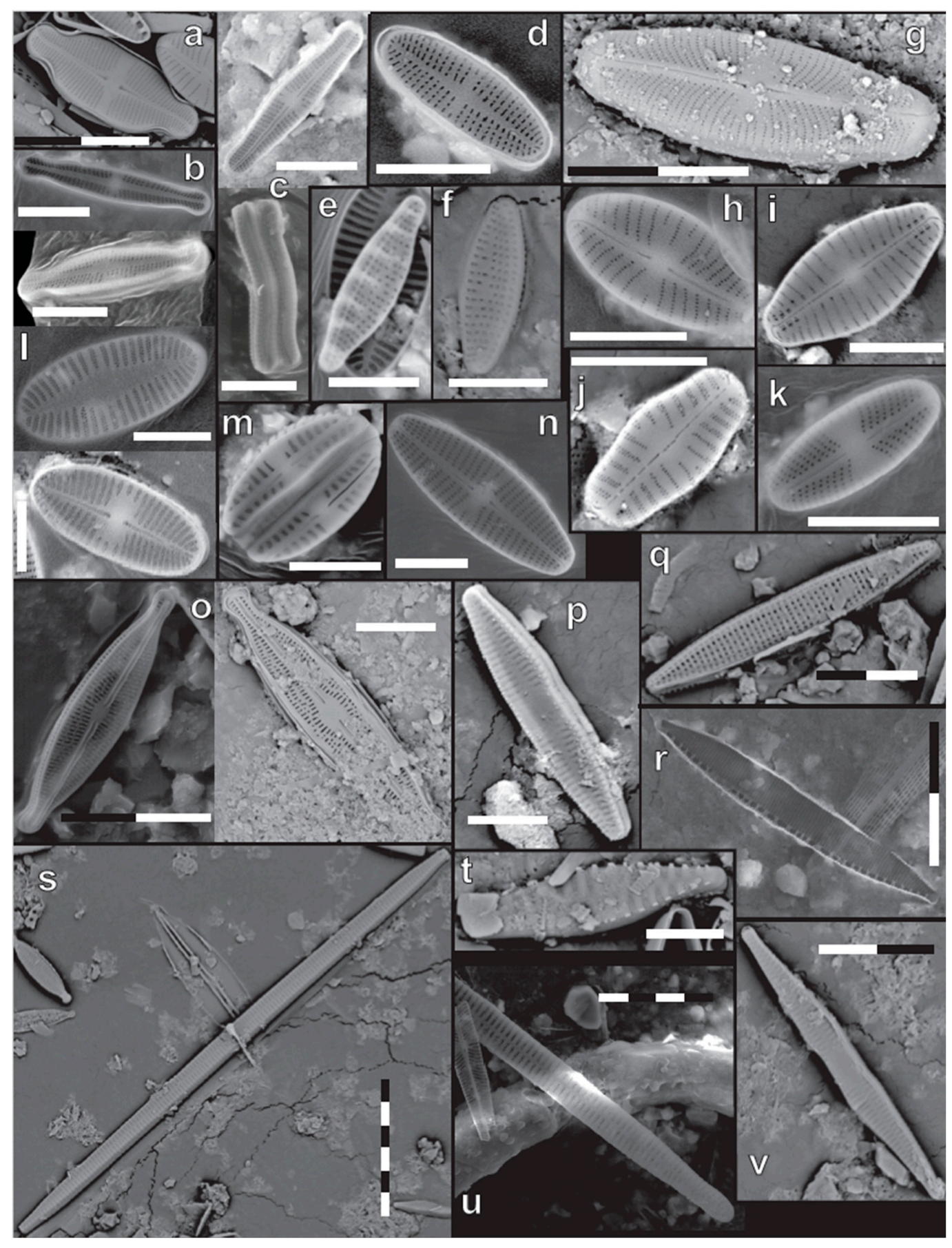

Figure 3. SEM photographs of some of the most common diatoms found in the water bodies. Each black or white part of the scale bar is $5 \mu \mathrm{m}$. Identifications: (a) Achnanthidium exiguum (Grunow) Czarnecki (raphe valve); (b) Achnanthidium macrocephalum (Hustedt) Round \& Bukhtiyarova (raphe and rapheless valve); (c) Achnanthidium minitissimum (Kützing) Czarnecki (raphe valve and girdle view); (d) Achnanthidium saprophilum (H.Kobayashi \& Mayama) Round \& Bukhtiyarova (rapheless valve); (e) Grunowia solgensis (A.Cleve) Aboal; (f) Nitzschia frustulum (Kützing) Grunow; (g) Sellaphora pupula (Kützing) Mereschkovsky; (h) Sellaphora cf. nigri (De Notaris) Wetzel \& Ector; (i) Geissleria sp. 2 Lange-Bertalot \& Metzeltin; (j) Sellaphora cf. saugerresii (Desmazières) C.E.Wetzel \& D.G.Mann; (k) Sellaphora cf. atomoides (Grunow) Wetzel \& Van de Vijver; (1) Platessa hustedtii (Krasske) Lange-Bertalot (raphe and rapheless valve); (m) Amphora pediculus (Kützing) Grunow; (n) Geissleria sp. 1 LangeBertalot \& Metzeltin; (o) Brachysira neoexilis Lange-Bertalot; (p) Fragilaria capucina Desmazières; (q) Nitzschia amphibia Grunow; (r) Nitzschia cf. palea (Kützing) W.Smith; (s) Ulnaria cf. unlabiseriata D.M.Williams \& B.Liu; (t) Punctastriata cf. mimetica E.A.Morales; (u) Ulnaria cf. biceps (Kützing) Compère; (v) Ulnaria cf. contracta (Østrup) E.A.Morales \& M.L.Vis. 


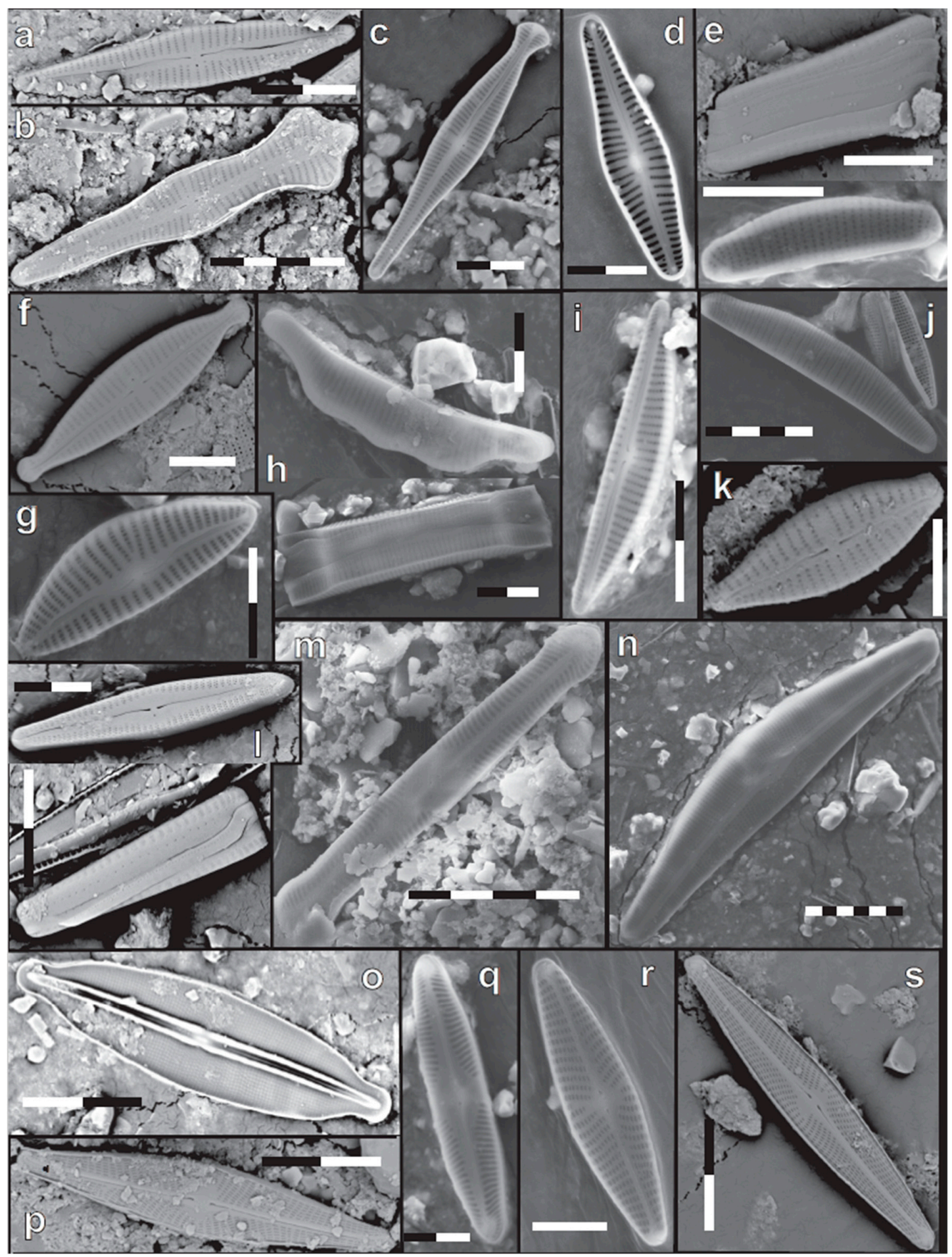

Figure 4. SEM photographs of some of the most common diatoms found in the water bodies. Each black or white part of the scale bar is $5 \mu \mathrm{m}$. Identifications: (a) Gomphonema gracile sl Ehrenberg; (b) Gomphonema acuminatum Ehrenberg; (c) Gomphonema pseudosphaerophorum H.Kobayasi; (d) Gomphonema cf. affine Kützing; (e) Eunotia rhomboidea Hustedt (girdle and valve view); (f) Gomphonema lagenula Kützing; (g) Cymbella affinis Kützing; (h) Eunotia pectinalis var. undulata (Ralfs) Rabenhorst (valve and girdle view); (i) Encyonema neogracile Krammer; (j) Eunotia cf. minor (Kützing) Grunow; (k) Gomphonema parvulum (Kützing) Kützing; (1) Gomphonema venusta Passy, Kociolek \& Lowe (valve and girdle view); (m) Pinnularia gibba (Ehrenberg) Ehrenberg; (n) Cymbella aspera (Ehrenberg) Cleve; (o) Frustulia crassinervia (Brébisson ex W.Smith) Lange-Bertalot \& Krammer; (p) Navicula cf. zanonii Hustedt; (q) Pinnularia divergens W.Smith; (r) Navicula cryptotenella Lange-Bertalot; (s) Navicula radiosa Kützing. 
Correspondence analysis was used to determine the relationship between hydrochemistry and the composition of the diatom assemblage [41,42]. Angolan taxa were grouped by hydrochemical preferences based on data from Gasse (1986), Gasse et al. (1995), Sonneman et al. (2000), Taylor et al. (2007a), and Spaulding et al. (2020) [13,35,37,38,43], although many taxa were missing data in all or some categories of interest. Correspondence analysis for each hydrochemical parameter was run on the formed groups and the percentage of the groups at each site to determine whether the groupings can predict the measured and calculated parameters (conductivity, $\mathrm{pH}$, temperature, alkalinity, and cations and anions). Because of the varied nature of the data presented in the literature, regional variability in diatom ecological preferences, and the possibility of misidentification or morphologically similar taxa with different ecological preferences, groupings do not represent specific, quantitative hydrochemical preferences. Rather, the typically quantitative parameters (conductivity, temperature, $\mathrm{pH}$, and alkalinity) are clustered along a gradient (where Group 1 is low and Group 5 is high) based on observed preferences in the aforementioned literature to show general trends of inferred hydrochemistry based on the observed diatom assemblages (Table S2). Thus, Chi-square could not be used to confirm the significance of the data, as categorical correspondence cannot account for the quantitative gradient for each parameter. Chi-square was used for categories that can be categorical and were not measured in the field, including pollution and trophic level.

\section{Results}

\subsection{Hydrochemical Results}

Four water bodies (Umbutu and Nandimba Tchivinguiro, cold springs; Leba, river; and Cascatinha da Zootécnica, waterfall pool) were sampled, with Leba River sampled from two locations along the reach of the river (Figure 2). Located on the Humpata Plateau, all water bodies have relatively high elevation, ranging from Cascatinha da Zootécnica at $1670 \mathrm{~m}$ to Umbutu at $1806 \mathrm{~m}$. Conductivity, TDS, and $\mathrm{pH}$ vary between Umbutu with the highest conductivity and TDS $(1035 \mu \mathrm{S} / \mathrm{cm}$ and $520 \mathrm{ppm}$, respectively) and lowest $\mathrm{pH}$ (7.16) and Cascatinha da Zootécnica with the lowest conductivity and TDS $(17 \mu \mathrm{S} / \mathrm{cm}$ and $8 \mathrm{ppm}$, respectively) and highest $\mathrm{pH}$ (8.26) (Table 1; Figure 5). Nearly all sites are of the $\mathrm{HCO}_{3}{ }^{-}$type with Umbutu of the $\mathrm{Mg} / \mathrm{Ca}-\mathrm{HCO}_{3}$ type, Nandimba Tchivinguiro of the $\mathrm{Mg}-\mathrm{HCO}_{3}$ type, Leba 1 of the $\mathrm{Ca} / \mathrm{Mg}-\mathrm{HCO}_{3}$ type, and Leba 2 of the $\mathrm{Na} / \mathrm{Ca}-\mathrm{HCO}_{3} / \mathrm{Cl}$ type. Only Cascatinha da Zootécnica is not of the $\mathrm{HCO}_{3}{ }^{-}$type, instead being of the Na-Cl type. Alkalinity ranges from $1 \mathrm{mg} / \mathrm{L}$ at Cascatinha da Zootécnica to $147 \mathrm{mg} / \mathrm{L}$ at Nandimba Tchivinguiro. Of the cations, $\mathrm{Na}^{+}, \mathrm{K}^{+}, \mathrm{Ca}^{2+}$, and $\mathrm{Mg}^{2+}$ all have a concentration greater than $1.00 \mathrm{mg} / \mathrm{L}$ in at least one locality (Table 1). $\mathrm{Ca}^{2+}$ and $\mathrm{Mg}^{2+}$ both have the greatest range, which reflects the dolomitic nature of the Leba Formation. Of the anions, $\mathrm{HCO}_{3}{ }^{-}$ has the highest molar concentration across the sites except at Cascatinha da Zootécnica where $\mathrm{Cl}^{-}$(the only other anion to have a concentration greater than $1.00 \mathrm{mg} / \mathrm{L}$ ) is the dominant anion. $\mathrm{NO}_{3}{ }^{-}$and $\mathrm{SO}_{4}{ }^{2-}$ concentrations, common indicators of agricultural and excremental waste pollution, range from 0.01 to 0.89 and 0.06 to $0.71 \mathrm{mg} / \mathrm{L}$, respectively. $\mathrm{PO}_{4}{ }^{3-}$, a common limiting nutrient for aquatic phytoplankton, ranges across the localities from 0.01 to $0.20 \mathrm{mg} / \mathrm{L}$. 


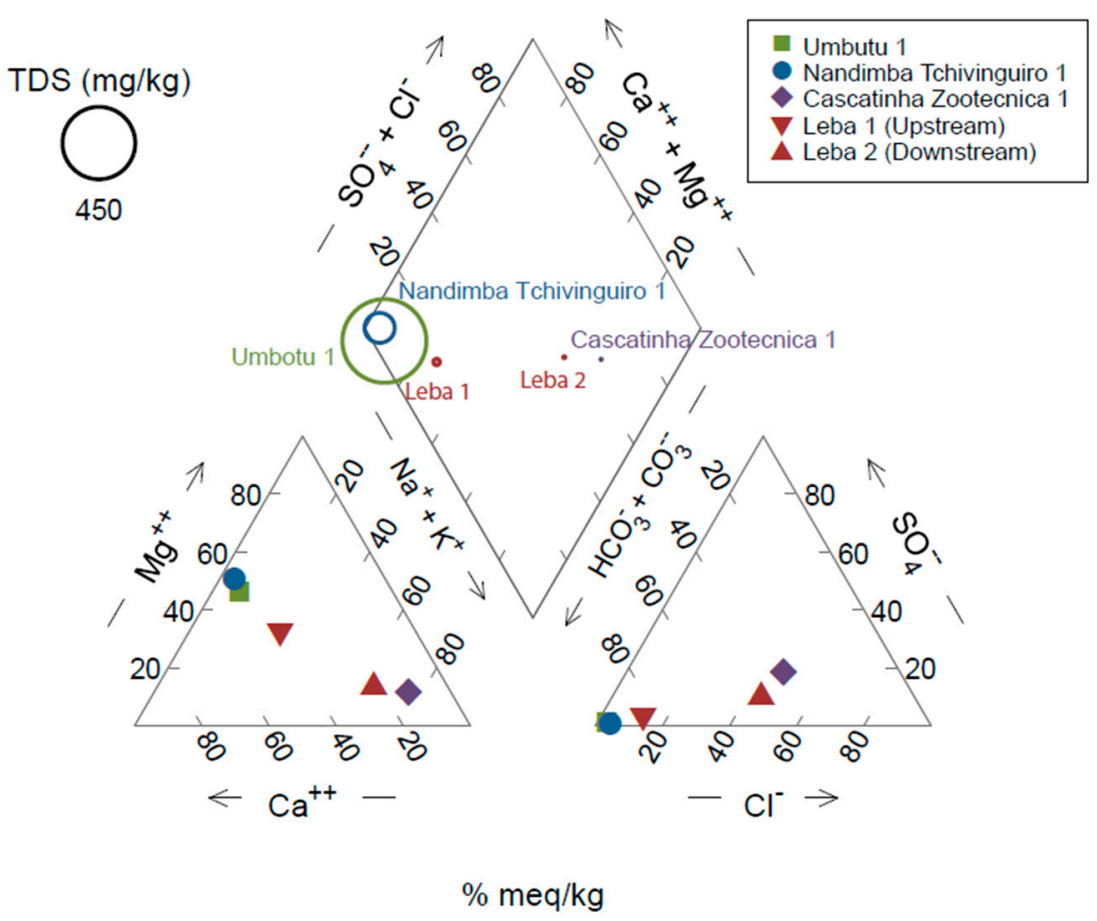

Figure 5. Piper diagram of sites made using Geochemist Workbench with total dissolved solids (TDS) represented by the size of the circle in the diamond.

\subsection{Diatom Assemblage Results}

Of the 91 diatom taxa identified, 44 taxa organized into 42 groups (four species, Geissleria sp. 1/Sellaphora cf. atomoides and Sellaphora cf. saugerressi/Geissleria sp. 2 are listed together as they were indistinguishable under the light microscope) are at least $2 \%$ abundant within a site's community (epilithic, epiphytic, epipelic, or episammic) (Table 2; Figures 3 and 4). The most abundant species in each water body with an abundance of at least $10 \%$ in a community are:

- Cascatinha da Zootécnica, Achnanthidium macrocephalum (Hustedt) Round \& Bukhtiyarova (all communities), Encyonema neogracile Krammer (epipelic), Eunotia cf. minor (Kützing) Grunow (epiphytic), E. rhomboidea Hustedt (epipelic and epiphytic), and Navicula cryptocephala Kützing (epilithic and epipelic)

- Nandimba Tchivinguiro, Achnanthidium minutissimum (Kützing) Czarnecki (epilithic and epiphytic), Grunowia solgensis (A. Cleve) Aboal (episammic), Geissleria sp. 1 and Sellaphora cf. atomoides (Grunow) Wetzel \& Van de Vijver (episammic), Navicula erifuga (OF Müller) Bory (epilithic), Nitzschia amphibia Grunow (all communities), N. frustulum (Kützing) Grunow (episammic), and Platessa hustedtii (Krasske) LangeBertalot (epiphytic)

- Umbutu, A. minutissimum (all communities), Gomphonema parvulum (Kützing) Kützing (all communities), Navicula cryptotenella Lange-Bertalot (epilithic), and Sellaphora pupula (Kützing) Mereschkowsky (epipelic and epiphytic)

- Leba 1, A. minutissimum (all communities), Navicula radiosa Kützing (all communities), and Ulnaria cf. biceps (Kützing) Lange-Bertalot (epilithic)

- Leba 2, A. macrocephalum (epililthic, epipelic, and episammic), Ulnaria cf. contracta (GS West) (epiphytic), G. paroulum (epilithic), and Navicula cf. zanonii Hustedt (all communities)

Taxa tend to be found in communities related to their life habits (i.e., Eunotia tend to be more present on epiphytic samples). It is uncommon for a species to be at least $10 \%$ abundant and not found, at least in trace amounts, in the other habitats. Therefore, to remove community bias based on each species' life habits, correspondence analysis was run on lumped communities for each water body rather than separately. 


\section{Discussion}

\subsection{Hydrochemistry}

Hydrochemistry is influenced by the source and chemistry of local precipitation, the residence time of water, local vegetation, anthropogenic pollution, and the lithological and hydrological properties of bedrock [40]. Given the proximity of the sites and similar historic annual rainfall records [24,25], differences in precipitation across the sites are likely minimal, meaning it is unlikely that precipitation is the main driver of local hydrochemistry. The residence time of the different water bodies is beyond the scope of this study and would require future sampling, although given the sedimentary nature of the bedrock and the high elevation, residence times are likely short. Because samples were collected during the dry season, local variation in vegetation is limited. Seasonally reduced vegetation and low fertility of local soils (which hinder deep root systems) likely lessen the impact macrophytes have on localized, seasonal fluctuations in water chemistry (such as $\mathrm{pH}$ ) during the dry season. Therefore, vegetation is anticipated to have a minimal impact on hydrochemistry. To understand pollution, one can focus on high levels of $\mathrm{SO}_{4}{ }^{2-}$ unrelated to lithological chemistry (typically from gypsum), as well as on other measured potential pollutants such as $\mathrm{NO}_{3}{ }^{-}$. If local pollution drives hydrochemistry, we anticipate that sites closer to Lubango, the second most populous city in Angola [44], would cluster together in Figure 5 and have higher concentrations of $\mathrm{NO}_{3}{ }^{-}$and $\mathrm{SO}_{4}{ }^{2-}$, following the assumption that locations with higher populations have higher potential for pollution. Cascatinha da Zootécnica has the largest population, followed by Umbutu and Leba 1 [44]. Livestock can also increase pollution, given the assumption that larger livestock populations have higher pollution potential. Umbutu has the largest population of ruminants per area [45]. Therefore, if Cascatinha da Zootécnica, Umbutu, and Leba 1 plot together on the piper diagram, local pollution may be driving hydrochemistry. In contrast, bedrock would be a driver of hydrochemistry if Leba 1, Umbutu, and Nandimba Tchivinguiro cluster together in Figure 5, given their similar sedimentary bedrock. Cascatinha da Zootécnica, which is also located within the Chela Group but downstream of metaluminous granitoid bedrock, would plot separately. Leba 2 would plot between these clusters because it lies within the same Chela sedimentary group as Leba 1, Umbutu, and Nandimba Tchivinguiro, but is surrounded by mafic sills (Figure 1C).

Based on these predictions, it appears that bedrock has the largest impact on local hydrochemistry (Figure 5). Umbutu and Nandimba Tchivinguiro cluster closely, with Leba 1 nearby, due to similar percentages of $\mathrm{HCO}_{3}{ }^{-}, \mathrm{Ca}^{2+}$, and $\mathrm{Mg}^{2+}$. Umbutu and Nandimba Tchivinguiro also have large TDS compared to the other water bodies, which are at least an order of magnitude smaller (Table 1). Leba 2 and Cascatinha da Zootécnica plot further away with higher percentages of $\mathrm{Cl}^{-}, \mathrm{Na}^{+}$, and $\mathrm{K}^{+}$. Umbutu, Leba 1, Leba 2, and Nandimba Tchivinguiro are all located within the Chela Group, either on the Cangalongue Formation of dolostones, siltstones, and Fe-rich sandstones, the Leba Formation of dolostones, or a combination of the two, given the uncertainty of local bedrock boundaries (Figure 1C,D). Input through the Leba and Cangalongue Formations likely leads to the high concentrations of $\mathrm{HCO}_{3}{ }^{-}$. In addition, both Nandimba Tchivinguiro and Umbutu are cold water springs. As waters move through the dolostones of the Leba Formation, high concentrations of $\mathrm{HCO}_{3}{ }^{-}, \mathrm{Ca}^{2+}$, and $\mathrm{Mg}^{2+}$ as well as high conductivity and TDS are expected. In contrast, Leba 1 and 2 likely have a larger input from surface waters. Input from surface runoff or smaller tributaries between Leba 1 and 2 may contribute to their variation and explain why they do not have similar hydrochemistries despite being only $4.6 \mathrm{~km}$ apart (Figure 2). In addition, Leba 2's bedrock is also interspersed with mafic sills and has higher amounts of $\mathrm{Na}^{+}$and $\mathrm{K}^{+}$compared to other sites within the Chela Group. Igneous input could explain why Leba 2 lies closest to Cascatinha da Zootécnica, which is influenced by granitoid bedrock, in Figure 5. The high concentrations of $\mathrm{Cl}^{-}, \mathrm{Na}^{+}$, and $\mathrm{K}^{+}$, compared to the other locations, could be due to more minerals such as hornblende, melilite, epidote, or biotite compared to the dolostone and siltstone bedrock of the other sites [46]. 
Although bedrock appears to be most influential on hydrochemistry, anthropogenic pollution may also have a minor influence. At rural locations with no factories, pollution from agriculture as well as excremental waste are more probable than industrial or urban pollutants. Contamination from waste can be evident through high conductivity and TDS as well as high levels of $\mathrm{NO}_{3}{ }^{-}$and $\mathrm{PO}_{4}{ }^{3-}$ [1,3]. None of the sites has dangerous levels of $\mathrm{NO}_{3}{ }^{-}$or $\mathrm{PO}_{4}{ }^{3-}$. While some sites have high conductivity and TDS, it is difficult to distinguish between anthropogenic and bedrock input. Given local land-use, agricultural pollution input is likely, such as at Umbutu where local cattle were herded into the spring during sample collection. Umbutu has the highest $\mathrm{PO}_{4}{ }^{3-}$ at $0.6 \mathrm{mg} / \mathrm{L}$, meaning some of this input could be related to waste pollution. In addition, Nandimba Tchivinguiro and Leba 2 are next to agricultural fields where fertilizer and/or manure could be used to aid production, affecting hydrochemistry. Therefore, although waste pollution does not appear to be a problem hydrochemically (aquatic bacteria have not been investigated), it still likely has an impact on the local water bodies based on observations.

\subsection{Diatoms as Indicators}

Of the 44 most abundant taxa, none are taxa that typically prefer saline/brackish waters such as Craticula, Mastogloia, or Anomoeoneis [47]. Achnanthidium and Navicula are present across all water bodies. Achnanthidium is a cosmopolitan and adaptive genus, particularly A. minutissimum, which is one of the most frequently occurring freshwater benthic diatoms globally [48]. Navicula s.l., which is represented by a different species in each water body, is a broad genus and occupies a wide range of hydrochemistries [49]. Cascatinha da Zootécnica is the only water body with a large percentage of Eunotia, which tend to live in the benthos of acidic, oligotrophic waters with low conductivity [49]. Nandimba Tchivinguiro has an abundance of small taxa, including varieties of Achnanthidium, Geissleria, Sellaphora, and small Nitzschia taxa, which tend to indicate highly oxygenated and mesoto eutrophic waters with moderate to high conductivities [49]. A lack of any Stephanodiscus in the samples (although biased due to the lack of planktonic samples), but an abundance of Nitzschia with occasional Ulnaria, means that phosphorus is likely the limiting nutrient in these water bodies rather than silicon given the preferred ratios of phosphorus versus silicon for each genus [50,51]. This is also evidenced by the low amount of phosphate that was measured in the field (Table 1).

Assessing diatom assemblages with water chemistry data provides information about which variables control the composition of local assemblages, which can later be used to determine hydrochemistry and pollution based on collected diatoms. It is important to recognize, however, that diatom communities can represent conditions across multiple seasons whereas collected water chemistry data represent a very short time frame. While this does not make analysis impossible, this bias could be the cause of inconsistencies between diatom-inferred chemistry data and measured data. Previous studies show that conductivity, $\mathrm{pH}$, and ionic composition tend to have the strongest correlations with diatom assemblages $[12,13]$. Unfortunately, besides conductivity, much of the diatom hydrochemical data are scarce. Therefore, exploratory correspondence analysis results will lead to future questions about interactions between diatom assemblages and hydrochemistry on the Humpata Plateau. These results show that conductivity and trophic level are best inferred by the diatom assemblages (those parameters have a large impact on the composition of the communities), although a lack of data or possible errors for the other parameters limit their interpretation.

\subsubsection{Conductivity}

Conductivity data for diatom taxa are often collected and reported from northern, eastern, and southern Africa [35,37], although statistically robust data are not always collected [12]. In general, water bodies with low conductivity, such as Cascatinha da Zootécnica, tend to have higher abundance of taxa that prefer low conductivity such as Encyonema neogracile, Eunotia cf. minor, and Eunotia rhomboidea, whereas water bodies with 
high conductivity, such as Nandimba Tchivinguiro, tend to have higher abundance of taxa that prefer moderate/high conductivity water such as Grunowia solgensis, Navicula erifuga, and Nitzschia cf. frustulum (Table 2). Figure 6 (which reflects the proportions of the groupings from Table $\mathrm{S} 2$ of the counted diatoms from each community) shows that all communities have a substantial proportion of diatoms located in the "low/medium" and/or "medium" conductivity categories. Water bodies with lower conductivity, including Cascatinha da Zootécnica, Leba 1, and Leba 2, have substantial portions of their diatoms in the "low conductivity" category, with Leba 1 's spread also in the "low/medium" category and Cascatinha da Zootécnica's and Leba 2's spread more evenly split between "low", "low/medium", and "medium" (except for Cascatinha da Zootécnica's epilithic community which is spread evenly across all groupings). Nandimba Tchivinguiro's groupings reflect its higher conductivity with larger proportions of its diatoms in the "medium" and "medium/high conductivity" categories. Umbutu, despite having the highest measured conductivity, has diatoms spread evenly across all four groupings. Nonetheless, at Umbutu, the epipelic, and epiphytic communities have a larger proportion in the "medium/high" category compared to all sites with low conductivity (Cascatinha da Zootécnica, Leba 1, and Leba 2), except for Cascatinha da Zootécnica's epilithic community (Figure 6). Correspondence analysis shows that Axis 1 is controlled by conductivity, with lower conductivities plotting negatively and higher conductivities plotting positively (Figure 7). While Umbutu does seem to be an outlier in this data, the diatom assemblages do appear to reliably decipher conductivity with Cascatinha da Zootécnica and Leba 2 plotting closest to the "low" grouping, Leba 1 closest to the "low/medium" grouping, and Nandimba Tchivinguiro closest to the "medium/high" grouping (Figure 7).
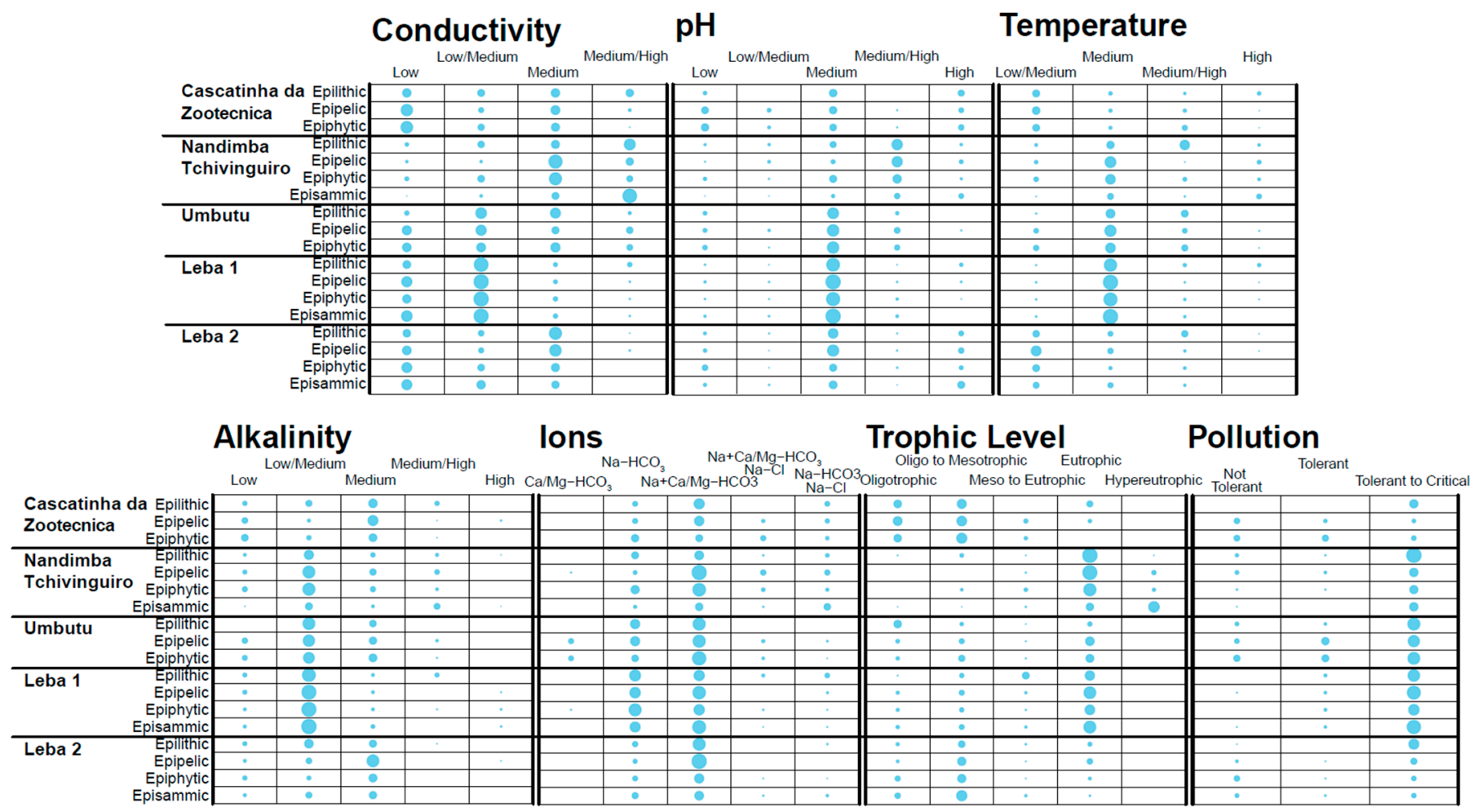

Figure 6. Balloon plots, which represent the percentage of the diatoms of each grouping based on the available data for each parameter, at each site divided by community. The organization for the groups is indicated in Table S2. 

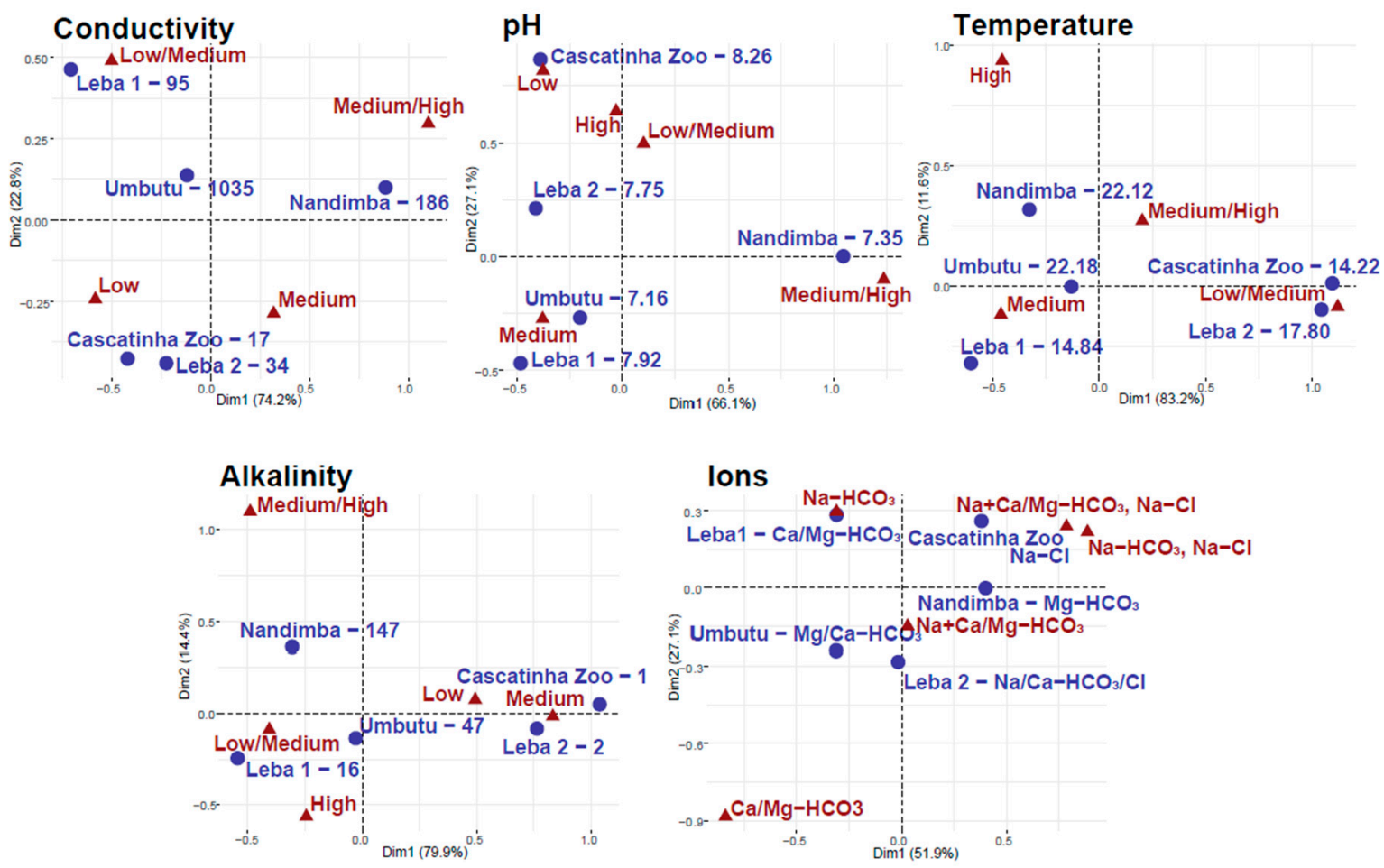

Trophic Level
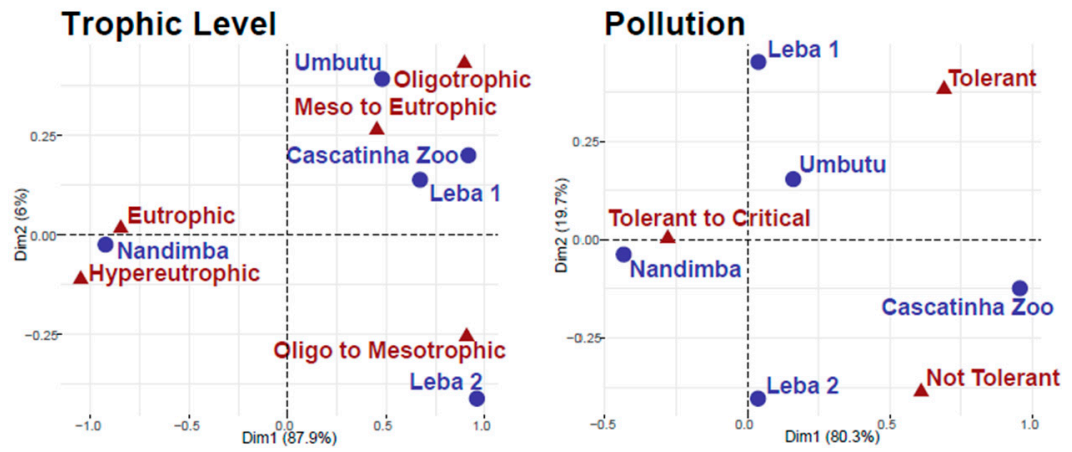

Figure 7. Correspondence analysis of the groupings for the different variables at each site. Chi-square values are only relevant for trophic level and pollution because the rest of the data are not purely categorical and/or were measured in the field. Chi-square values for trophic level and pollution are 2356 and 346, respectively.

\subsection{2. $\mathrm{pH}$}

Correspondence analysis shows diatom assemblages do not accurately infer $\mathrm{pH}$, despite having the most available preference data besides conductivity. $\mathrm{pH}$ clusters show the largest proportion of all diatoms in the "medium" pH category, except for Nandimba Tchivinguiro where diatoms are mostly in the "medium/high" category, except for the episammic taxa which are spread across all categories (Figure 6). Given that the $\mathrm{pH}$ of the sites ranges from neutral at Umbutu to slightly alkaline at Cascatinha da Zootécnica and that the taxa observed are mostly circumneutral to slightly alkaliphilic in their preference, the large proportion in the "medium" $\mathrm{pH}$ group is not surprising. Cascatinha da Zootécnica evenly splits its diatoms between the "low", "medium", and "high" $\mathrm{pH}$ clusters despite having the highest measured $\mathrm{pH}$. Nonetheless, Cascatinha da Zootécnica does have more diatoms in the "high" category compared to most other communities besides Nandimba Tchivinguiro episammic and Leba 2 's epilithic, epipelic, and episammic communities (Figure 6). Axis 1 of Figure 7 is not exclusively controlled by $\mathrm{pH}$ and has less predictive power compared to Axis 1 in the conductivity biplot. The most obvious inconsistency is the placement of the "high" pH category between the "low" and "low/medium" groupings. This pattern makes sense given that both Cascatinha da Zootécnica and Leba 2 had larger 
proportions of taxa that prefer "high" $\mathrm{pH}$ in the balloon plot but confuses the interpretation of how $\mathrm{pH}$ might determine diatom assemblages. These results may be biased by the similar measured $\mathrm{pH}$ across the water bodies (Table 1 ) or by errors in reported $\mathrm{pH}$ preferences causing errors in the $\mathrm{pH}$ diatom groupings (Table S2). It is also possible that there could have been equipment failure at Cascatinha da Zootécnica in collecting the appropriate $\mathrm{pH}$ measurements, seeing as the rest of the sites plot near reasonable "medium" groups in the biplot (Figure 7).

\subsubsection{Temperature}

Despite sparse and sometimes unreliable data regarding how diatoms are impacted by temperature [12], diatom assemblages may weakly infer accurate relative water temperatures on the Humpata Plateau. Waters with lower temperatures (Cascatinha da Zootécnica $14.22{ }^{\circ} \mathrm{C}$ and Leba $217.80^{\circ} \mathrm{C}$ ) have the majority of their diatoms in the "low/medium" temperature category (Figure 6). The outlier of this trend is Leba 1 which, despite having a recorded temperature of $14.84^{\circ} \mathrm{C}$, has a balloon plot similar to the higher temperature sites (Nandimba Tchivinguiro $22.12{ }^{\circ} \mathrm{C}$ and Umbutu $22.18^{\circ} \mathrm{C}$ ), with the majority of taxa plotting in the "medium" temperature category (besides Nandimba Tchivinguiro epilithic which has its majority in the "medium/high" category). Nonetheless, the warmer waters of Nandimba Tchivinguiro and Umbutu have more taxa in the "medium/high" and "high" categories than the other water bodies showing that temperature may have some predictive power in determining the diatom assemblages (Figure 6). This is less clear on the biplot where the axes are controlled by other variables, given that neither Axis 1 nor Axis 2 align the temperature gradient correctly (Figure 7). Despite this, Nandimba Tchivinguiro and Umbutu plot closest together and Cascatinha da Zootécnica and Leba 2 cluster near the "low/medium" temperature grouping, reflecting the measured patterns (Figure 7). One complication with temperature data, however, is that temperature was only taken on one day at one time at each site even though temperature of these sites likely changes throughout the day. Therefore, it is difficult to deduce how diatom assemblages and temperature may be related. These results indicate that diatom assemblages cannot infer temperature either due to data collection bias or that diatom assemblages are instead impacted by the influence of temperature on other variables such as ionic composition, $\mathrm{pH}$, and conductivity as a physical parameter [12].

\subsubsection{Alkalinity and Ionic Species}

Alkalinity may be inferable using the diatom assemblages, although limited preference data hinder interpretations (Table S2). This is supported by the tails of the data which mimic the calculated trends, such as how Leba 2 and Cascatinha da Zootécnica (besides Cascatinha da Zootécnica's epilithic community) with low alkalinity are mostly split between "low" to "medium" alkalinity clusters or how Nandimba Tchivinguiro, as the location with the highest alkalinity, has more diatoms in the "medium/high" category compared to nearly all other communities (Figure 6). In contrast, an overrepresentation of taxa that prefer "low/medium" and "medium" alkalinity complicate the ability to see if diatom assemblages can infer alkalinity. The lack of data is evident in the alkalinity biplot where neither Axis 1 nor Axis 2 represent alkalinity (Figure 7). Despite this, the sites are located near to other sites with similar alkalinity calculations, such as Cascatinha da Zootécnica and Leba 2 plotting together, although closest to the "medium" cluster. It is therefore difficult to say much about whether or not alkalinity can be inferred by the diatom communities.

The ionic species mirror the preferred alkalinity, as a measure of $\mathrm{HCO}_{3}{ }^{-}$in the system, of diatom taxa. Understanding the ionic data is complicated given the difficulty of organizing taxa with broad ionic preferences and the added complication that data include both optimal cations and anions. For example, while communities of the Ca- and/or $\mathrm{Mg}-\mathrm{HCO}_{3}$ type waters such as Nandimba Tchivinguiro epipelic, Umbutu epipelic and epiphytic, and Leba 1 epiphytic are the only water bodies with taxa in the $\mathrm{Ca} / \mathrm{Mg}-\mathrm{HCO}_{3}$ 
grouping, the $\mathrm{Na}-\mathrm{HCO}_{3}$ grouping includes taxa from each community, which is reasonable considering each water body is either of the $\mathrm{Na}$ - or $\mathrm{HCO}_{3}$-type (Figure 6). The inability to distinguish between the role of cations versus anions in diatom preference groupings therefore hinders interpretation of the correspondence analysis. Axis 1 of the biplot may relate to the presence of $\mathrm{Cl}^{-}$in the water with the $\mathrm{Na}+\mathrm{Ca} / \mathrm{Mg}-\mathrm{HCO}_{3}, \mathrm{Na}-\mathrm{Cl}$ and $\mathrm{Na}-\mathrm{HCO}_{3}$, $\mathrm{Na}-\mathrm{Cl}$ groups plotting more positively on Axis 1 (Figure 7). Axis 2 appears to be related to the presence of $\mathrm{Na}^{2+}$ in the water, with the $\mathrm{Ca} / \mathrm{Mg}-\mathrm{HCO}_{3}$ grouping plotting far more negatively than the others, although, the conflation of both anions and cations limits the ability to deduce patterns across these data (Figure 7).

\subsubsection{Trophic Levels and Pollution}

Understanding how assemblages might infer accurate trophic levels and pollution is extremely limited due to sparse preference data and no reference data collected in the field. Despite minimal preference data, trophic levels may be inferred by the diatom assemblages, with a Chi-square value of 2356. Axis 1, which explains $87.9 \%$ of the data's variance, appears to be controlled by trophic level with negative numbers corresponding to hyperto eutrophic conditions and positive numbers corresponding to oligo- to mesotrophic conditions (Figure 7). Based on the biplot, Nandimba Tchivinguiro is hyper/eutrophic, Leba 2 is oligo/mesotrophic, and Leba 2, Cascatinha da Zootécnica, and Umbutu are all oligo to eutrophic (Figure 7). In contrast, the sampled water bodies do not cluster closely with pollution categories and have a Chi-Square value of 346, giving the appearance that diatom assemblages may be unable to infer pollution reliably. The biplot does appear to divide the pollution tolerance (although not directly along Axis 1 or 2) with the three groupings plotting in three distinct areas across the biplot (Figure 7). From this plot, we anticipate that Nandimba Tchivinguiro to be most polluted and Cascatinha da Zootécnica or Leba 2 to be least polluted (Figure 7). This may represent a bias in that water chemistry data is only a snapshot of the chemistry when the samples were collected, but that collected diatoms can represent multiple seasons and could have survived through varying degrees of pollution. One method to further explore this outcome includes using diatom indices for pollution and trophic levels [52]. While this could help interpret data, such indices, which are often created in Europe, they have mixed results in their effectiveness for African samples [53-55].

\section{Conclusions}

This research includes the first description of water chemistry and diatom communities on the Humpata Plateau in southwestern Angola. Water chemistry is most influenced by bedrock composition, although more research must be completed to determine the impact of other variables such as vegetation, residence time, and anthropogenic pollution. Diatom communities across the water bodies were documented and correspondence analysis was used to determine whether diatom communities can infer hydrochemical variables for future waterquality and paleoclimate studies. Diatoms appear to have predictive power for conductivity and trophic level, although sparse data on diatom chemistry preference limits understanding of their ability to infer $\mathrm{pH}$, temperature, alkalinity, ionic species, and pollution.

Diatom counts may be used for diatom indices on pollution or trophic levels to learn more about how diatoms can benefit hydrochemical studies in this region. Such indices, however, are untested in the region (as well as throughout most of Africa) and would need to be explored further before any definitive conclusions can be made. During the next field season during the wet season, more water and diatom samples will be collected as well as samples from surrounding sediments and bedrock to learn more about the chemistries of these surfaces. Work conducted during the wet season will determine whether these observed patterns are visible at other points during the year. The second field season will provide more insight into bedrock/water interactions, trophic levels, pollution, and evaporation/precipitation budget, particularly related to comparisons between the wet and dry seasons. $\delta^{18} \mathrm{O}$ and $\delta^{2} \mathrm{H}$ will be used to classify the local meteoric water line. 
The persistent research in this area will provide more clarity about how diatoms and hydrochemistry data can be used to better understand local waters and pollution to benefit the livelihoods of local communities.

Supplementary Materials: The following are available online at https://www.mdpi.com/article/ 10.3390/geosciences11090359/s1, Figure S1: Supplementary Diatom Plates, Table S1: Full Diatom Count, Table S2: Diatom Ecological Groupings.

Author Contributions: Field work, E.R. and D.d.M.; conceptualization, E.R. and A.J.; diatom identification, E.R. and J.R.S.; labwork and analysis, E.R.; figures and charts, E.R. and A.J.; writing—original draft preparation, E.R.; writing—review and editing, D.d.M., J.R.S. and A.J. All authors have read and agreed to the published version of the manuscript.

Funding: Fieldwork for this research was funded by the Leakey Foundation, Dissertation Fieldwork Grants, and The National Geographic Society, grant number EC-57233R-19, awarded to D.d.M. Writing was funded by Nicholas Conard under the Graduiertenförderung des Landes BadenWürttemberg. We acknowledge support by Open Access Publishing Fund of University of Tübingen to supplement publishing costs.

Data Availability Statement: Data is contained within the supplementary material. The data presented in this study are available in Table S1.

Acknowledgments: Special thanks to the Department of Geology and Mining at the Instituto Superior Politécnico da Huíla-Universidade Mandume Ya Ndemufayo in Lubango for their support and collaboration on this project. Thanks to Fernando Castro Lopes, John Mendehlson and Nídia Loureiro for background information and help in the field. Thank you to Monika Markowska for help with preparation for fieldwork. Special thanks to Beatriz Barros, Rui Francisco, Chiloia, and Eduardo Henrique for their assistance in the field. Thank you to Michael Marks for running cation and anion samples. Special thanks to Tati Miranda for help taking SEM photographs. Thank you to Nicholas Conard and the Evolution of Cultural Modernity Fellowship for funding during the writing process. Special thanks to Ran Feng, Lisa Park Boush, and Christian Tryon for additional guidance and comments.

Conflicts of Interest: The authors declare no conflict of interest. The funders had no role in the design of the study; in the collection, analyses, or interpretation of data; in the writing of the manuscript, or in the decision to publish the results.

\section{References}

1. Lapworth, D.J.; Nkhuwa, D.C.W.; Okotto-Okotto, J.; Pedley, S.; Stuart, M.E.; Tijani, M.N.; Wright, J. Urban Groundwater Quality in Sub-Saharan Africa: Current Status and Implications for Water Security and Public Health. Hydrogeol. J. 2017, 25, 1093-1116. [CrossRef] [PubMed]

2. Paca, J.M.; Santos, F.M.; Pires, J.C.M.; Leitão, A.; Boaventura, R.A.R. Quality Assessment of Water Intended for Human Consumption from Kwanza, Dande and Bengo Rivers (Angola). Environ. Pollut. 2019, 254, 113037. [CrossRef] [PubMed]

3. Silva, M.M.; Gomes, E.M.C.; Isaías, M.; Azevedo, J.M.M.; Zeferino, B. Spatial and Seasonal Variations of Surface and Groundwater Quality in a Fast-Growing City: Lubango, Angola. Environ. Earth Sci. 2017, 76, 1-17. [CrossRef]

4. WHO. Guidelines for Drinking-Water Quality, 4th ed.; World Health Organization: Geneva, Switzerland, 2017.

5. Godfrey, S.; Obika, A. Improved Community Participation: Lessons from Water Supply Programmes in Angola. Commun. Dev. J. 2004, 39, 156-165. [CrossRef]

6. Nicholson, S.E.; Funk, C.; Fink, A.H. Rainfall Over the African Continent from the 19th through the 21st Century. Glob. Planet. Chang. 2018, 165, 114-127. [CrossRef]

7. Gasse, F. Hydrological Changes in the African Tropics since the Last Glacial Maximum. Quat. Sci. Rev. 2000, 19, 189-211. [CrossRef]

8. Battarbee, R.W.; Jones, V.J; Flower, R.J; Cameron, N.G.; Bennion, H.; Carvalho, L.; Juggins, S. Diatoms. In Tracking Environmental Change Using Lake Sediments. Volume 3: Terrestrial, Algal, and Siliceous Indicators; Smol, J.P., Birks, H.J.B., Last, W.M., Eds.; Kluwer Academic Publishers: Dordrecht, The Netherlands, 2001.

9. Fritz, S.C.; Cumming, B.F.; Gasse, F.; Laird, K.R. Diatoms as indicators of hydrologic and climatic change in saline lakes. In The Diatoms: Applications for the Environmental and Earth Sciences; Stoermer, E.F., Smol, J.P., Eds.; Cambridge University Press: Cambridge, UK, 2010.

10. Cocquyt, C.; Ndjombo, E.L.; Tsamemba, S.T.; wa Malale, H.N.S. Freshwater Diatoms in the Democratic Republic of the Congo: A Historical Overview of the Research and Publications. Phytokeys 2019, 136, 107. [CrossRef] 
11. Birks, B.; John, H. Strengths and Weaknesses of Quantitative Climate Reconstructions Based on Late-Quaternary Biological Proxies. Quat. Int. 2010. [CrossRef]

12. Juggins, S. Quantitative Reconstructions in Palaeolimnology: New Paradigm Or Sick Science? Quat. Sci. Rev. 2013, 64, 20-32. [CrossRef]

13. Gasse, F.; Juggins, S.; Khelifa, L.B. Diatom-Based Transfer Functions for Inferring Past Hydrochemical Characteristics of African Lakes. Palaeogeogr. Palaeoclimatol. Palaeoecol. 1995, 117, 31-54. [CrossRef]

14. Vanormelingen, P.; Verleyen, E.; Vyverman, W. The diversity and distribution of diatoms: From cosmopolitanism to narrow endemism. Biodivers. Conserv. 2008, 17, 393-405. [CrossRef]

15. Soininen, J.; Teittinen, A. Fifteen important questions in the spatial ecology of diatoms. Freshw. Biol. 2019, 64, 2071-2083. [CrossRef]

16. Huntley, B.J.; Russo, V.; Lages, F.; Ferrand, N. Biodiversity of Angola; Springer Cham: Basel, Switzerland, 2019. [CrossRef]

17. Lopes, F.C.; Pereira, A.J.; Mantas, V.M.; Mpengo, H.K. Morphostructural Characterization of the Western Edge of the Huila Plateau (SW Angola), Based on Remote Sensing Techniques. J. Afr. Earth Sci. 2016, 117, 114-123. [CrossRef]

18. Lopes, F.C.; Ramos, A.M.; Gomes, C.R.; Ussombo, C.C. The Geoheritage of Lubango-Tundavala Road Traverse in the Serra Da Leba (SW Angola): Outcrops Characterization and Numerical Assessment for Outdoor Educational Activities and Geoconservation Purpose. J. Afr. Earth Sci. 2019, 157, 103510. [CrossRef]

19. Correia, H. Sobre a existência de rochas vulcanoclásticas na Formação da Chela (Região do Planalto da Humpata). Ciênc. Geol. 1973, 1, 27-32.

20. Correia, H. O Grupo da Chela e Formação da Leba como novas unidades litoestratigráficas resultantes da redefinição da Formação da Chela na região do Planalto da Humpata (Sudoeste de Angola). Bol. Soc. Geol. 1976, 20, 65-130.

21. Pereira, E.; Tassinari, C.C.G.; Rodrigues, J.F.; Van-Dúnem, M.V. New data on the deposition age of the volcano-sedimentary Chela Group and its Eburnean basement: Implications to post-Eburnean crustal evolution of the SW of Angola. Comun. Geol. 2011, 98, 29-40.

22. de Matos, D.; Martin, A.C.; Senna-Martinez, J.C.; Pinto, I.; Coelho, A.G.; Ferreira, S.S.; Oosterbeek, L. Review of Archaeological Research in Angola. Afr. Archaeol. Rev. 2021. [CrossRef]

23. Pombo, S.; de Oliveira, R.P. Evaluation of Extreme Precipitation Estimates from TRMM in Angola. J. Hydrol. 2015, 523, 663-679. [CrossRef]

24. SASSCAL WeatherNet-Monthly Values. Available online: www.sasscalweathernet.org/weatherstat_monthly_AO_we.php (accessed on 10 October 2020).

25. CCKP. Climate Change Knowledge Portal. 2021. Available online: https://climateknowledgeportal.worldbank.org/downloaddata (accessed on 14 April 2021).

26. Tyson, P.D.; Preston-Whyte, R.A. The Weather and Climate of Southern Africa; Oxford University Press Southern Africa: Cape Town, South Africa, 2000.

27. Tyson, P.D. Climatic Change and Variability in Southern Africa; Oxford University Press: Cape Town, South Africa, 1986.

28. Chase, B.M.; Niedermeyer, E.M.; Boom, A.; Carr, A.S.; Chevalier, M.; He, F.; Meadows, M.E.; Ogle, N.; Reimer, P.J. Orbital Controls on Namib Desert Hydroclimate Over the Past 50,000 Years. Geology 2019, 47, 867-871. [CrossRef]

29. Meissner, R. Interaction and existing constraints in international river Basins. In International Waters in Southern Africa; Nakayama, M., Ed.; United Nations University Press: Tokyo, Japan, 2003; pp. 249-273.

30. Heyns, P. Water Resource Management in Southern Africa. In International Waters in Southern Africa; Nakayama, M., Ed.; United Nations University Press: Tokyo, Japan, 2003; pp. 5-37.

31. Lindenmaier, F.; Miller, R.; Fenner, J.; Christelis, G.; Dill, H.G.; Himmelsbach, T.; Kaufhold, S.; Lohe, C.; Quinger, M.; Schildknecht, F.; et al. Structure and Genesis of the Cubango Megafan in Northern Namibia: Implications for its Hydrogeology. Hydrogeol. J. 2014, 22, 1307-1328. [CrossRef]

32. Wellington, J.H. The Kunene River and the Etosha Plain. S. Afr. Geogr. J. 1938, 20, 21-32. [CrossRef]

33. Kelly, M.G.; Adams, C.; Graves, A.C.; Jamieson, J.; Krokowski, J.; Lycett, E.B.; Murray-Bligh, J.; Prichard, S.; Wilkins, C. The Trophic Diatom Index: A User's Manual; Environmental Agency: Bristol, UK, 2001.

34. Battarbee, R.W. Diatom Analysis. In Handbook of Holocene Palaeoecology E Palaeohydrology; Berglund, B.E., Ed.; The Blackburn Press: Caldwell, NJ, USA, 1986; pp. 527-570.

35. Gasse, F. East African Diatoms: Taxonomy, Ecological Distribution. Bibl. Diatomol. 1986, 11, 201.

36. Cocquyt, C. Diatoms from the Northern Basin of Lake Tanganyika. Bibl. Diatomol. 1998, 39, 1-274.

37. Taylor, J.C.; Harding, W.R.; Archibald, C.G.M. An Illustrated Guide to Some Common Diatom Species from South Africa; Water Research Commission: Pretoria, South Africa, 2007.

38. Spaulding, S.A.; Bishop, I.W.; Edlund, M.B.; Lee, S.; Furey, P.; Jovanovska, E.; Potapova, M. Diatoms of North America. Available online: https: / / diatoms.org/species (accessed on 26 August 2019).

39. Eby, G. Chapter 6: Carbon Chemistry. In Principles of Environmental Geochemistry; Waveland Press, Inc.: Long Grove, IL, USA, 2016; pp. 129-161. 
40. Bartos, T.T.; Ogle, K.M. Water Quality and Environmental Isotopic Analyses of Ground-Water Samples Collected from the Wasatch and Fort Union Formations in Areas of Coalbed Methane Development-Implications to Recharge and Ground-Water Flow, Eastern Powder River Basin, Wyoming. Available online: https://pubs.usgs.gov/wri/wri024045/htms/report2.htm (accessed on 10 December 2020).

41. Benzecri, J.-P. Correspondence Analysis Handbook; Marcel Dekker Inc.: New York, NY, USA, 1992.

42. Kassambara, A. Practical Guide to Principal Component Methods in R. 2017. Available online: http://www.sthda.com/english/ articles/31-principal-component-methods-in-r-practical-guide/ (accessed on 15 February 2021).

43. Sonneman, J.A.; Sincock, A.; Fluin, J.; Reid, M.; Newall, P.; Tibby, J.; Gell, P. An Illustrated Guide to Common Stream Diatom Species from Temperate Australia; Cooperative Research Centre for Freshwater Ecology Identification Guide No 33; Adalaide University: Adalaide, Australia, 2000.

44. WorldPop. 2018. (www.worldpop.org-School of Geography and Environmental Science, University of Southampton; Department of Geography and Geosciences, University of Louisville; Departement de Geographie, Universite de Namur) and Center for International Earth Science Information Network (CIESIN), Columbia University. Global High Resolution Population Denominators Project-Funded by the Bill and Melinda Gates Foundation (OPP1134076). Available online: https://dx.doi.org/10 .5258/SOTON/WP00660 (accessed on 16 March 2021).

45. Conchedda, G.; Cinardi, G.; Steinfeld, H. Africa Ruminants Tropical Livestock Units (TLU). 2015. Available online: http: //www.fao.org/geonetwork/srv/en/metadata.show?id=52752\&currTab=simple (accessed on 16 March 2021).

46. USGS. Metaluminous Granite. Available online: https: / / mrdata.usgs.gov / catalog/term-simple.php?term=4.4.2.2\&thcode=4 (accessed on 16 December 2020).

47. Owen, R.B.; Potts, R.; Behrensmeyer, A.K.; Ditchfield, P. Diatomaceous Sediments and Environmental Change in the Pleistocene Olorgesailie Formation, Southern Kenya Rift Valley. Palaeogeogr. Palaeoclimatol. Palaeoecol. 2008, 269, 17-37. [CrossRef]

48. Potapova, M.; Hamilton, P.B. Morphological and Ecological Variation within the Achnanthidium Minutissimum (Bacillariophyceae) Species Complex. J. Phycol. 2007, 43, 561-575. [CrossRef]

49. Taylor, J.C.; Cocquyt, C. Diatoms from the Congo and Zambezi Basins-Methodologies and Identification of the Genera. Afr. J. Aquat. Sci. 2019. [CrossRef]

50. Kilham, P.; Kilham, S.S.; Hecky, R.E. Hypothesized Resource Relationships among African Planktonic Diatoms. Limnol. Oceanogr. 1986, 31, 1169-1181. [CrossRef]

51. Descy, J.-P.; Sarmento, H. Microorganisms of the East African Great Lakes and their Response to Environmental Changes. Freshw. Rev. 2008, 1, 59-73. [CrossRef]

52. Abassi, T.; Abassi, S.A. Water Quality Indices; Elsevier: Amsterdam, The Netherlands, 2012.

53. Bellinger, B.J.; Cocquyt, C.; O’Reilly, C.M. Benthic Diatoms as Indicators of Eutrophication in Tropical Streams. Hydrobiologia 2006, 573, 75-87. [CrossRef]

54. Taylor, J.C.; van Vuuren, M.S.J.; Pieterse, A.J.H. The Application and Testing of Diatom-Based Indices in the Vaal and Wilge Rivers, South Africa. Water SA 2007, 33. [CrossRef]

55. Dalu, T.; Bere, T.; Froneman, P.W. Assessment of Water Quality Based on Diatom Indices in a Small Temperate River System, Kowie River, South Africa. Water SA 2016, 42, 183. [CrossRef] 